\title{
REVIEWS
}

\section{Measuring, modelling and projecting coastal land subsidence}

\author{
Manoochehr Shirzaei® ${ }^{1 凶}$, Jeffrey Freymueller ${ }^{2}$, Torbjörn E. Törnqvist $\mathbb{1}^{3}$, \\ Devin L. Galloway4, Tina Dura (1) ${ }^{1}$ and Philip S. J. Minderhoud (1) ${ }^{5,6}$
}

Abstract | Coastal subsidence contributes to relative sea-level rise and exacerbates flooding hazards, with the at-risk population expected to triple by 2070. Natural processes of vertical land motion, such as tectonics, glacial isostatic adjustment and sediment compaction, as well as anthropogenic processes, such as fluid extraction, lead to globally variable subsidence rates. In this Review, we discuss the key physical processes driving vertical land motion in coastal areas. Use of space-borne and land-based techniques and the associated uncertainties for monitoring subsidence are examined, as are physics-based models used to explain contemporary subsidence rates and to obtain future projections. Steady and comparatively low rates of subsidence and uplift owing to tectonic processes and glacial isostatic adjustment can be assumed for the twenty-first century. By contrast, much higher and variable subsidence rates occur owing to compaction associated with sediment loading and fluid extraction, as well as large earthquakes. These rates can be up to two orders of magnitude higher than the present-day rate of global sea-level rise. Multi-objective predictive models are required to account for the underlying physical processes and socio-economic factors that drive subsidence.

A large proportion of the world's population lives on low-elevation $(<10 \mathrm{~m})$ land near the sea ${ }^{1,2}$, much of which is subject to subsidence due to natural and anthropogenic processes ${ }^{3}$. As of $2005, \sim 40$ million people and assets worth $5 \%$ of global gross domestic product were exposed to a 1-in-100-year coastal flooding hazard ${ }^{4}$. By 2070, the exposed population is expected to grow more than threefold, and the value of property exposed is expected to increase to $\sim 9 \%$ of the projected gross domestic product, with the USA, Japan and the Netherlands having the most exposure ${ }^{4}$. However, these estimates often rely only on projections of global average sea-level rise and do not account for vertical land motion (VLM), in terms of subsidence (downward VLM) or uplift (upward VLM) of the land surface. A different estimate of exposure could result when VLM is taken into account, particularly considering recent findings that the elevation of many coastal lowlands has, to date, been considerably overestimated ${ }^{5}$.

The recent increase in global mean sea level (GMSL) has led to a present-day rate of rise of $\sim 3.35 \mathrm{~mm}$ per year (REF.'); GMSL rise since 1900 is mostly attributed to accelerated ice-mass loss of glaciers and ice sheets, plus the thermal expansion of ocean water ${ }^{7}$. However, the relative sea level (RSL), defined here as the elevation difference between the sea surface and the solid Earth ${ }^{8}$, excluding the dynamic sediment surface ${ }^{9}$, is of particular relevance for assessing the effects of sea-level change at any given location. RSL change is defined as the sum of geocentric sea-level change plus $\mathrm{VLM}^{8}$. Note that the sediment-accretion rate, which has sometimes been invoked as a term in the RSL equation ${ }^{10}$, merely affects local water depth, not RSL. VLM is driven by natural processes, such as glacial isostatic adjustment (GIA $)^{11-13}$, tectonics and earthquakes ${ }^{14,15}$, and sediment consolidation, including natural compaction owing to sediment deposition (loading) ${ }^{16-19}$, as well as anthropogenic effects caused by peat oxidation following drainage ${ }^{20-24}$ and the compaction of aquifer systems and hydrocarbon reservoirs accompanying the extraction of subsurface fluids ${ }^{20,25,26}$ (FIG. 1).

These drivers can be divided into shallow processes affecting depths of less than $\sim 25 \mathrm{~m}$ (for example, compaction of Holocene sediments) and deep processes (such as tectonics and compaction of pre-Holocene strata $)^{27}$. VLM can be much greater than nearby geocentric sea-level rise alone and, in turn, GMSL rise, which is estimated, in part, based on tide-gauge records. Thus, knowing how much, where and why coastal land subsides and how its rate varies over time is essential to evaluating hazards associated with sea-level rise and estimating GMSL rise.

During the twenty-first century, the rate of RSL rise is expected to increase, not only due to continued thermal 


\section{Key points}

- Realistic estimates of the impact of sea-level rise on coastal communities require knowledge of coastal subsidence.

- Subsidence rates due to glacial isostatic adjustment and basin tectonics are steady, except in places that experience contemporary ice loss.

- Processes such as natural sediment compaction, organic-matter oxidation, aquifer-system and hydrocarbon-reservoir compaction, and large earthquakes cause coastal-subsidence rates that are highly variable in space and time.

- Human effects in the coastal zone can accelerate subsidence, with rates up to two orders of magnitude higher than present-day rates of geocentric sea-level rise.

- State-of-the-art, physics-based numerical models enable quantification of present and prediction of future coastal subsidence for a range of different natural and anthropogenic processes.

- Coastal subsidence is a highly complex problem with large spatio-temporal variability owing to multiple processes, requiring multidisciplinary approaches to characterize the driving mechanisms and to elucidate their individual contributions, as well as to enable predictions.

\section{Drivers of coastal subsidence}

Before discussing the wide range of processes that cause coastal subsidence, we highlight the distinction between VLM in static (such as urban) and dynamic (such as wetland) landscapes. In the former, land-elevation changes are generally equivalent to VLM, whereas in the latter, VLM must be separated from changes in surface elevation due to deposition or erosion - common phenomena in coastal zones. This separation is a non-trivial task that is often overlooked. Capturing VLM in static landscapes is relatively straightforward using, for example, space-geodetic techniques. However, dynamic landscapes require subsurface methods to isolate the role of subsidence. Subsurface methods also offer an important key to understanding driving mechanisms.

Natural processes. Natural processes that drive coastal subsidence operate on a wide range of spatial and temporal scales, including long geologic timescales (FIG. 1 b). Thermal subsidence due to cooling of the mantle, which results in a thicker and denser lithosphere, could contribute to coastal subsidence. However, its rate $(\ll 1 \mathrm{~mm}$ per year) is much slower than the processes discussed below $^{44,45}$. Thus, we do not discuss it further herein.

At active plate margins, such as Cascadia, Alaska, Japan, Central and South America, and Indonesia, earthquakes are the result of sudden fault slip that releases elastic energy stored over the preceding decades to centuries, as part of the earthquake cycle ${ }^{15,33,46-48}$. When an oceanic plate subducts beneath a continental plate, an offshore trench develops near where the ocean plate is subducting (FIG. 1a, bottom left). The overriding continental plate is compressed during the interseismic period, producing subsidence near the trench and uplift landward of the trench; VLM can be as large as several millimetres per year. During an earthquake (the coseismic period), the accumulated stress is released owing to slip on the fault, resulting in extension of the overriding plate and sudden, metre-scale vertical motion offshore and decimetre to metre-scale vertical motion along the coast, the effects of which can extend $\sim 300-600 \mathrm{~km}$ perpendicular to the tren $\mathrm{ch}^{49-52}$. Whether the coastal zone uplifts or subsides during an earthquake depends on the location of the shoreline relative to the fault-slip patch and the distribution of slip on the fault ${ }^{52}$. Large earthquakes are followed by a postseismic deformation phase, potentially lasting years or decades, during which afterslip occurs within the fault zone and the viscoelastic mantle relaxes the coseismic stress changes, causing transient vertical motions of the land surface ${ }^{52,53}$. For example, the viscoelastic relaxation of the mantle after the 2004 Sumatra-Andaman earthquake produced $20-30 \mathrm{~mm}$ of subsidence in Bangkok, Thailand ( $~ 800 \mathrm{~km}$ away from the rupture zone) in the first 5 years after the earthquake $e^{54}$, worsening flooding hazards.

Along passive margins, particularly in large depocentres, normal faulting can also substantially contribute to coastal subsidence ${ }^{55-58}$. These normal faults, commonly growth faults, represent seaward failure under the gravity of thick, unbuttressed deposits (FIG. 1a, bottom right). Growth faults typically form when higher-density sediments (such as sands) overlie weak and deformable 
a

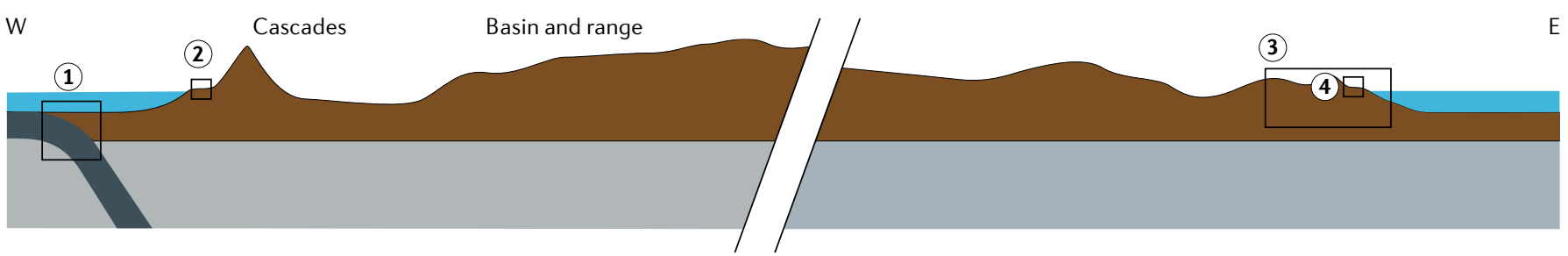

(1) Tectonic uplift or subsidence

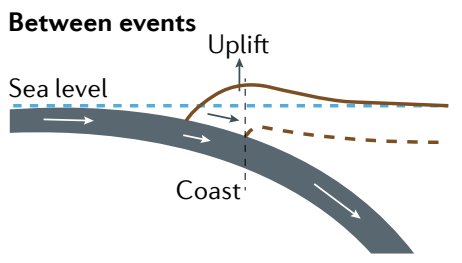

Earthquake

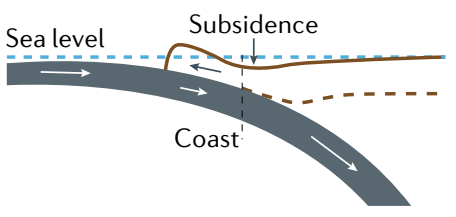

(2) Fluid extraction

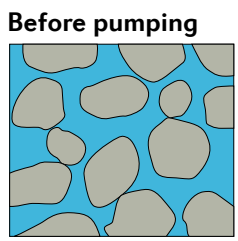

After pumping

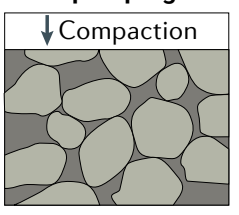

(3) Glacial isostatic adjustment or sediment loading

Melting ice sheet or removal of sediment

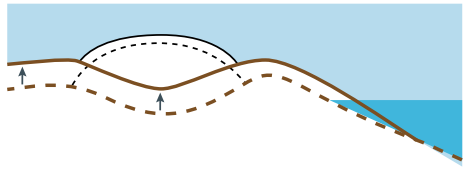

New solid Earth surface

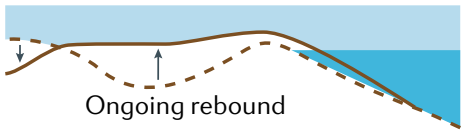

(4) Sediment compaction or faulting

Compaction

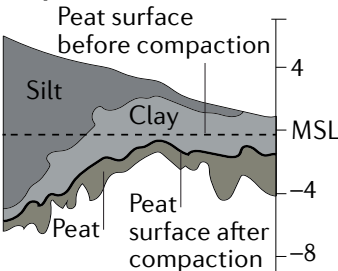

Faulting

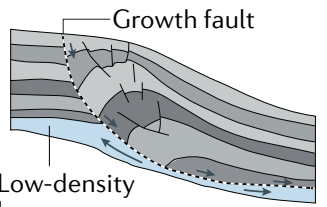

layer

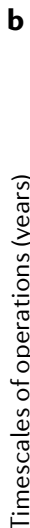

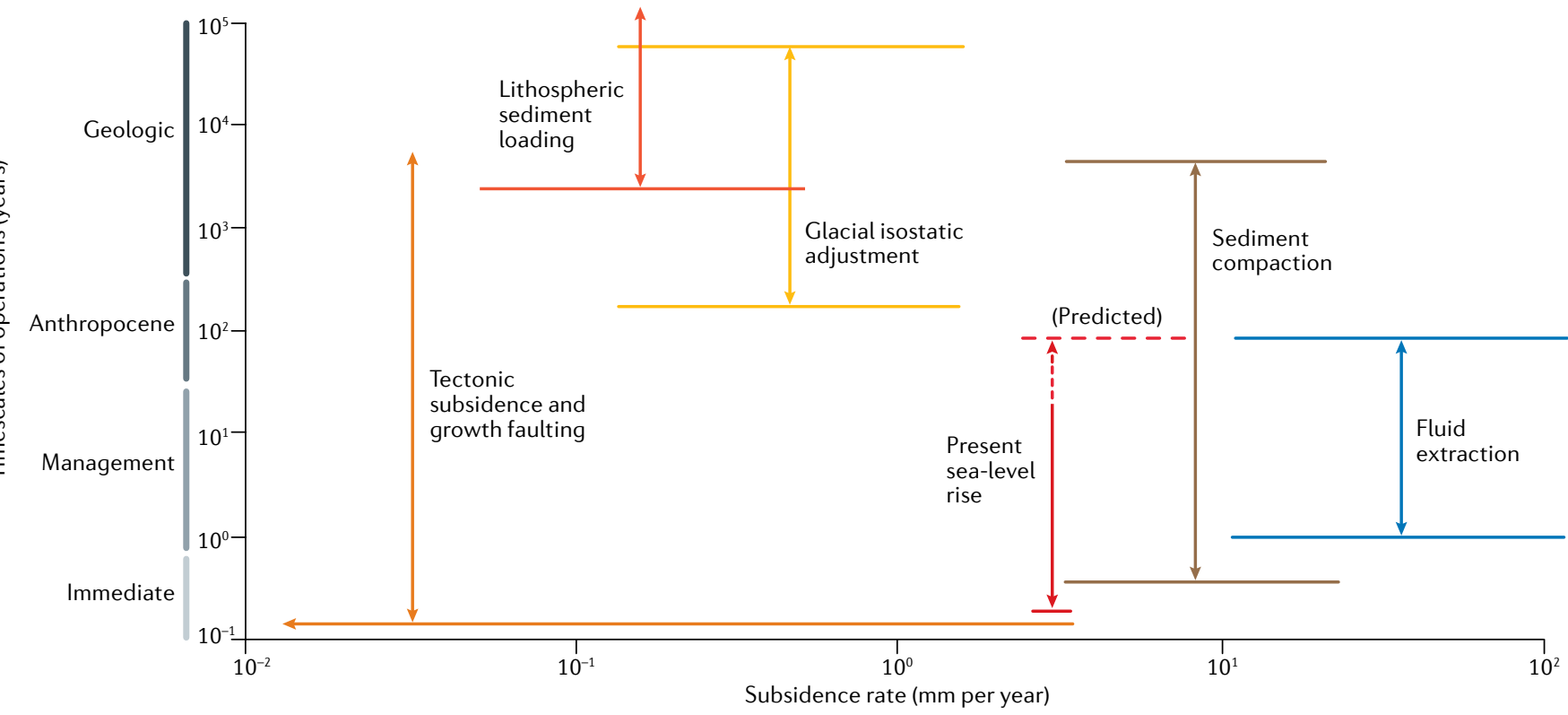

Fig. 1 | Conceptual model of mechanisms causing land subsidence in the coastal zone. a|The top part shows a schematic profile of the surface topography across North America. The highlighted areas are affected by different processes that cause vertical land motion. From west $(\mathrm{W})$ to east $(\mathrm{E})$, these processes are earthquake cycling along the Cascadia subduction zone ${ }^{188}$, the effects of pumping groundwater, the response of the solid Earth to decay of the Laurentide Ice Sheet or removal of a sediment load ${ }^{72}$ (note that the position of the shoreline relative to the load varies around the world and that the addition of ice sheet or sediment load causes an identical but opposite response), and sediment compaction and growth faulting. $\mathbf{b}$ | The rates and timescales on which the mechanisms shown in panel a operate. MSL, mean sea level. Panel a ('Tectonic uplift or subsidence', bottom left) adapted with permission from REF. ${ }^{276}$, Wiley. Published in 1994 by the American Geophysical Union. Panel $\mathbf{b}$ adapted with permission from REF. ${ }^{179}$, Wiley.

strata (typically muds or evaporites) $)^{59-62}$. Driven by gravity, growth faults initiate near the surface and propagate downward as the overburden loading continues; over the long term, systems of growth faults exhibit substantial displacements ${ }^{62-64}$. Unlike subduction faults, these faults often have a concave-up (listric) geometry ${ }^{64,65}$, attributed to a vertical change in rheology combined with shear stress along lithological interfaces ${ }^{62,63}$. A combination 
of levelling and tide-gauge data suggests that faulting is required to adequately explain deep subsidence in the Mississippi Delta, USA ${ }^{66}$. However, the relative contribution to subsidence from faulting versus other mechanisms in this region has been challenged ${ }^{58,67}$.

GIA causes vertical displacements, gravity-field changes and ocean-mass redistributions on a global scale ${ }^{13,68-72}$, affecting multiple components of RSL rise (FIG. 1 a, bottom, second from right). GIA accounts for VLM due to loading and unloading of the lithosphere by ice sheets and associated changes in ocean water mass. Ice sheets cause isostatic depression (subsidence) in the near field (beneath the ice sheets) and a forebulge (uplift) immediately outside the periphery of the ice sheets and beyond. Subsequent ice-sheet melt causes rebound of the lithosphere in the near field, which persists today, along with subsidence in the regions previously occupied by the forebulge. The contemporary rate of GIA is $\sim 10 \mathrm{~mm}$ per year of uplift in near-field regions (such as central Scandinavia and Hudson Bay, Canada) that were covered by ice sheets during the last glacial, and $\sim 1-2 \mathrm{~mm}$ per year of subsidence in intermediate-field regions (for example, New Jersey, USA) located on the periphery of the previous ice sheets ${ }^{73,74}$. Additional contributions to GIA occur in places that are currently losing ice mass, such as Antarctica and Alaska, USA, where uplift rates can be several times those in former centres of glaciation ${ }^{75-78}$. For example, in south-east Alaska, uplift rates exceed $30 \mathrm{~mm}$ per year in several areas, almost entirely due to local ice loss over the past 200 years ${ }^{77}$.

Isostatic adjustments are not limited to changing ice (and associated water) loads ${ }^{72}$. Several studies have proposed that the response of the lithosphere to sedimentary isostatic adjustment (SIA) can result in subsidence rates as high as a few millimetres per year in large depocentres, such as the Mississippi Delta ${ }^{79-81}$ and the Ganges-Brahmaputra ${ }^{82,83}$ (Bangladesh and India) Delta. Over geologic timescales, SIA can be explained in terms of the lithospheric-flexure model ${ }^{84}$. The flexure of an elastic lithosphere over an inviscid mantle is equivalent to a fully relaxed response from GIA or SIA. By contrast, the elastic over viscoelastic conditions used in GIA models apply over shorter timescales while the mantle is viscously responding to the load change. Moreover, a change in terrestrial water storage causes modifications to the purely elastic response to ongoing load changes ${ }^{85}$, which can vary continually and, in some places, such as Bangladesh, with a large annual cycle of up to $6 \mathrm{~cm}$ as measured by GNSS data ${ }^{86}$.

Compaction of unconsolidated sediment under its own weight or owing to overburden loading can also cause coastal subsidence (FIG. $1 \mathrm{a}$, bottom right); this is often a dominant factor in major depocentres ${ }^{19,87-90}$. When sediment accretion leads to an increase in effective stress, pore fluid is expelled, causing hydrostatic compaction $^{91-93}$. Sediment compaction can be particularly rapid over relatively short timescales (decades to centuries $)^{90,94,95}$. For example, coastal Louisiana, USA, exhibits a contemporary subsidence rate of $\sim 9 \mathrm{~mm}$ per year $\left(\right.$ REF. $\left.^{96}\right)$, albeit with large spatial variability, and local rates that can be several times higher ${ }^{34}$. Compaction of shallow Holocene strata ( $<5 \mathrm{~m}$ deep), including peat beds ${ }^{90}$, accounts for at least $60 \%$ of total subsidence in this area ${ }^{87}$. In the San Francisco Bay Area, USA, subsidence rates as high as $10 \mathrm{~mm}$ per year are observed over areas underlain by artificial fill and Holocene mud ${ }^{97}$. Compaction rates can be as high as $\sim 25-41 \mathrm{~mm}$ per year, as measured in the Mekong Delta, Vietnam ${ }^{19}$. However, these high compaction rates do not lead to elevation loss, as accretion rates are even higher ( $37-68 \mathrm{~mm}$ per year), currently resulting in net elevation gain ${ }^{98}$. Compaction is coupled with sediment accretion, whereby increased accretion rates lead to increased subsidence rates, whereas sediment starvation can result in lowered subsidence rates ${ }^{34}$. This somewhat counter-intuitive relationship is not always recognized and should not be confused with the fact that sediment starvation often results in coastal degradation and land loss, independent of subsidence.

Anthropogenic processes. Extracting fluids from aquifer systems or hydrocarbon reservoirs commonly leads to compaction and consequent land subsidence ${ }^{99-106}$ (FIG. 1a bottom, second from left). This deformation is governed by the principle of effective stress, that is, the total stress minus pore-fluid pressure. In soil mechanics and the mechanics of aquifer-system compaction, the relation is generally reduced to consideration of the vertical stress components or those normal to an arbitrary horizontal plane within the sediments ${ }^{99,100,103,104,106-110}$. When fluids are extracted from aquifer systems or hydrocarbon reservoirs, pore-fluid pressure decreases. Thus, for constant total stress, which can generally be represented by the geostatic stress or load of the saturated and undersaturated overlying sediments or rocks, the effective stress increases. Some aquifer systems are more susceptible to compaction than others. Appreciable compaction can occur in heterogeneous systems comprising unconsolidated sediments with a substantial fraction of finegrained deposits (silts and clays) of generally lower permeability and higher compressibility than coarsegrained deposits (sands and gravels). Fine-grained deposits can be widely interspersed in aquifer systems and/or occur as well-defined hydrostratigraphic units, such as interbeds and aquitards. For all aquifer systems, some degree of reversible elastic deformation occurs when the effective ${ }^{111}$ stress remains below the preconsolidation stress threshold ${ }^{25,111}$. This elastic deformation typically results in small-magnitude, recoverable displacements (on the millimetre to centimetre scale) of the land surface, and commonly occurs in susceptible aquifer systems subject to cyclical trends of groundwater extraction and recharge ${ }^{112}$. For susceptible aquifer systems, when the effective stress exceeds the preconsolidation stress threshold, deformation (compaction) is inelastic and, generally, permanent (irreversible) land subsidence results ${ }^{113-116}$. In these susceptible aquifer systems, inelastic (or viscous) compaction is often associated with the rearrangement (packing) of the finegrained material. The compressibility of the interbeds and aquitards in the inelastic stress range is typically at least an order of magnitude greater than compressibility in the elastic stress range. Thus, for equivalent material thicknesses, inelastic compaction is often at least an 
order of magnitude more than elastic compaction in these susceptible aquifer systems.

Land subsidence due to aquifer-system compaction typically varies spatially and temporally, depending on regionally integrated effects resulting from individual extraction wells, the seasonal cycles of drawdown superimposed on longer-term trends, as well as the variable distribution of aquifer-system properties, variability in groundwater-demand-driven extraction rates and variability in hydroclimatic conditions (for example, drought) that influence groundwater recharge ${ }^{117,118}$. In the Mekong Delta, increased extraction of groundwater has accelerated aquifer-system compaction ${ }^{119}$, with average subsidence rates of $16 \mathrm{~mm}$ per year at groundwater-monitoring wells during 2006-2010 (REF. ${ }^{120}$ ), increasing to $20-50 \mathrm{~mm}$ per year during 2014-2019 (REF. ${ }^{121}$ ). Portions of the Mississippi Delta experienced $\sim 8-12 \mathrm{~mm}$ per year of subsidence during 1965-1993 owing to hydrocarbon extraction $^{122}$ and the Houston-Galveston region in Texas, USA, experienced subsidence rates of $50 \mathrm{~mm}$ per year during 1993-2000 and $30 \mathrm{~mm}$ per year during 2004-2011, mostly due to groundwater extraction ${ }^{123}$.

Although sediment compaction occurs naturally, land-use changes in coastal lowlands (such as draining wetlands or infrastructural loading) can enhance compaction by increasing stress $\mathrm{s}^{24,124}$ and organic-matter decomposition (oxidation) ${ }^{20,22}$, which, for example, has resulted in subsidence rates of up to $13 \mathrm{~mm}$ per year in portions of the western Netherlands ${ }^{125,126}$.

\section{Measuring coastal subsidence}

Measurements that resolve the spatial and temporal variability of land subsidence are crucial to accurately account for the role of subsidence in flooding hazards. In this section, we review ground-based and space-borne monitoring techniques that have substantially improved our ability to monitor VLM at various spatial and temporal scales, and discuss the associated challenges and opportunities.

Stratigraphic and palaeoenvironmental methods. The coastal sedimentary record contains information on long-term RSL change and VLM. Geological reconstructions of RSL change depend on sea-level indicators ${ }^{127,128}$ : physical, biological or chemical features (for example, marine terraces, microfossils and stable-carbon-isotope signatures of organic remains) that have a well-defined relationship with tide levels ${ }^{129}$. Using quantitative techniques, this relationship can be used to reconstruct the past elevation within the tidal frame in which sea-level indicators found in cores or outcrops formed ${ }^{130}$. There has been a substantial effort over the past 10-15 years to assemble comprehensive global databases of palaeo sea-level information, most notably for the period since the Last Glacial Maximum 9 . This information can provide insight into the drivers of land subsidence in coastal areas and the relative contribution of subsidence to RSL change ${ }^{41,81,90,131}$. For example, a comprehensive RSL database for the past $4 \mathrm{kyr}$ (a time interval with a comparatively small meltwater contribution to GMSL change) along the US East Coast was used to explore the spatial variability of GIA over the late Holocene ${ }^{132}$. By resolving the subsidence due to the collapse of the proglacial forebulge, it was possible to subtract the GIA signal from tide-gauge records to estimate a mean twentieth-century rate of sea-level rise for this region of $1.8 \pm 0.2 \mathrm{~mm}$ per year.

The sedimentary record in tidal wetlands adjacent to subduction zones can reflect the VLM associated with the strain accumulation and release of the earthquake cycle ${ }^{133}$. Repeated sequences of organic-rich tidal-wetland soils formed during the interseismic period, sharply overlain by tidal mud deposited following decimetre-scale coseismic subsidence, record earthquakes over thousands of years ${ }^{134}$. Along the US Pacific Northwest Coast, where the Cascadia subduction zone is in the late stages of interseismic deformation ${ }^{135}$, gradual uplift of the overriding plate is causing an RSL fall of $1.5-3.0 \mathrm{~mm}$ per year $\left(\mathrm{REF}^{136}{ }^{13}\right.$ ). However, stratigraphic studies from Cascadia marshes that document repeated past coseismic subsidence along hundreds of kilometres of shoreline suggest that, at some point in the next few centuries, this trend of interseismic uplift will likely be reversed by sudden, decimetre-scale coseismic subsidence ${ }^{137}$, instantaneously dropping large swaths of coastal land below sea level ${ }^{138}$.

Subsidence patterns are more complicated in deltas, where both shallow and deep processes operate with different spatial and temporal signatures. Radiocarbon dating of sediment cores of the top of a late Holocene peat bed, assumed to be formed $\sim 30 \mathrm{~cm}$ below current mean sea level, coupled with the cored depths of the top of the peat bed revealed millennial-scale compaction rates of up to $5 \mathrm{~mm}$ per year in the Mississippi Delta that could locally reach $10 \mathrm{~mm}$ per year over shorter timescales ${ }^{90}$. This finding has been corroborated by more recent research using different methods ${ }^{34}$. These rates are broadly comparable to those obtained in the Ganges-Brahmaputra Delta ${ }^{82}$ and Rhine-Meuse Delta, the Netherlands ${ }^{24}$.

Land-based instrumental methods. Levelling is among the oldest geodetic methods used for measuring subsidence and uplift within a network of benchmarks, by carrying an elevation from a known (ideally stable) reference point to other points ${ }^{139,140}$ (FIG. 2a). This technique uses a precisely levelled telescope to measure the elevation difference between two points, by summing incremental vertical displacements of a graduated rod (differential levelling) or by measuring vertical angles (trigonometric levelling) ${ }^{139}$. Levelling is one of the most precise geodetic tools for measuring elevation change, and historical levelling surveys provide multi-decadal observations ${ }^{141}$. Levelling is also used routinely to monitor the local stability of tide gauges so that RSL change is determined relative to a network of benchmarks. Various factors determine the accuracy of levelling measurements, including the equipment, field procedure, atmospheric conditions and corrections applied to field observations ${ }^{139}$. Random errors in levelling surveys (in millimetres) are proportional to $\beta L^{0.5}$, where $L$ is the survey distance (in kilometres) and $\beta$ is an empirical uncertainty that scales with distance and ranges from $0.5 \mathrm{~mm} \mathrm{~km}^{-0.5}$ for the highest-order modern networks 
to $6 \mathrm{~mm} \mathrm{~km}^{-0.5}$ for the lowest-order nineteenth-century networks ${ }^{142}$. Today, however, long-distance levelling is rare because it is time-consuming, labour-intensive and expensive.
Borehole extensometers can provide continuous measurements of the $1 \mathrm{D}$ changes in the thickness of various layers at (sub-)hourly sampling rates and millimetre-level precision ${ }^{141,143,144}$. Extensometers are,
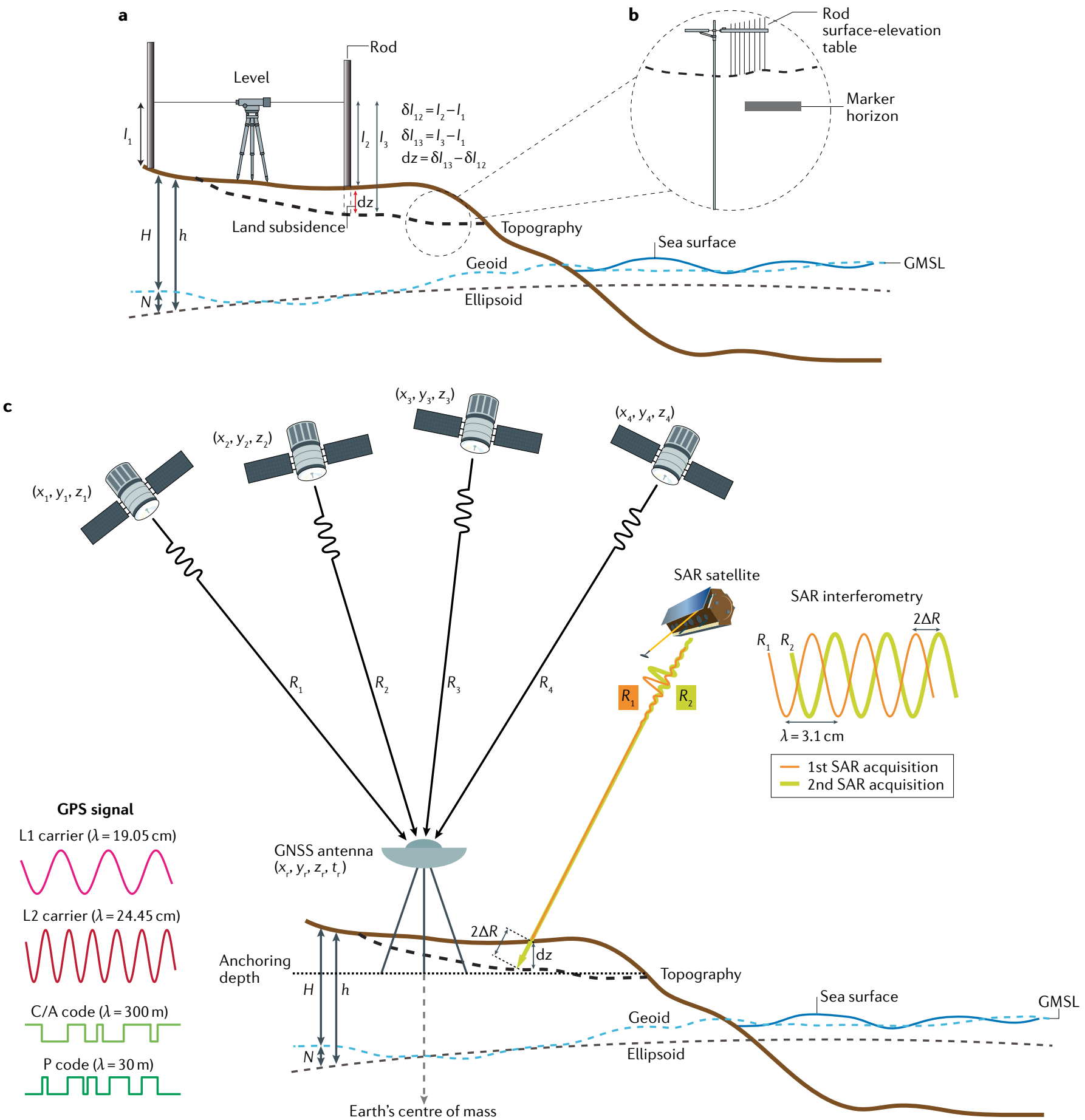

Fig. 2 | Measuring coastal land subsidence. $\mathbf{a}, \mathbf{b} \mid$ Schematics showing how levelling (panel $\mathbf{a}$ ) and rod surface-elevation table (panel $\mathbf{b}$ ) are used to measure subsidence. $\mathbf{c}$ | Schematic showing the operation of a global navigation satellite system (GNSS) ${ }^{162}$ and interferometric synthetic aperture radar (InSAR) $)^{277}$ for measuring subsidence. The GNSS antenna is mounted on a monument that is usually attached to stable ground through anchoring at depth or using an engineered structure. Thus, the GNSS measurement of vertical land motion can miss compaction of sediments shallower than the anchoring depth. GNSS requires simultaneous observations to at least four satellites for positioning, whereas InSAR uses two observations to a satellite during a period of time to measure land-elevation change in the satellite line-of-sight. $\lambda$, wavelength; $\Delta R$, range change between two SAR acquisitions; GMSL, global mean sea level; GPS, Global Positioning System; $H$, orthometric height; $h$, ellipsoid height; l, level; $N$, geoid height; $R$, range between satellite and receiver (for GPS) or ground cell (for InSAR); SAR, synthetic aperture radar; $t$, receiver clock error. 
thus, suitable for distinguishing between various factors that determine subsidence over a compacting aquifer and that act at different depth intervals ${ }^{145}$. To measure the compaction of layers at different depths within a single borehole, an extensometer can include an array of spider magnets anchored at each depth, the readings of which refer to the top or bottom of the borehole ${ }^{146}$. Maintaining extensometers is often expensive, and performing corrections for environmental artefacts (such as temperature and pressure changes) is challenging ${ }^{141}$. For the period that satellite observations are available, validation tests indicate a good agreement between extensometer observations and subsidence measured by InSAR and GNSS ${ }^{114}$.

The rod surface-elevation table (RSET) is an instrument that was developed for measuring surface-elevation change owing to shallow subsidence in coastal wetlands ${ }^{16,147-149}$ (FIG. 2b). It includes nine pins mounted on a horizontal arm, which is anchored by a rod with a typical length of $1-25 \mathrm{~m}\left(\mathrm{REFS}^{149,150}\right)$. The pins slide downward to measure the surface elevation, and repeat surveys enable surface-elevation change to be determined. To obtain shallow subsidence rates, vertical accretion must also be measured, which is often done through cryogenic coring to determine the sediment thickness above artificial marker horizons ${ }^{151}$. In one study, 274 RSETs and marker horizons were used to determine the present-day shallow subsidence rate in coastal Louisiana by subtracting the rate of surface-elevation change from the vertical-accretion rate $^{34}$, yielding a shallow subsidence rate of $6.8 \pm 7.9 \mathrm{~mm}$ per year over a 6-10-year period. Using the same methods, the vulnerability of mangroves to RSL rise throughout the Indo-Pacific region was examined ${ }^{98}$. The measured shallow subsidence rates of $8.2 \pm 12.5 \mathrm{~mm}$ per year (up to $49.5 \mathrm{~mm}$ per year) indicate that that the majority of the investigated mangroves receive insufficient sediment to keep up with present-day RSL rise.

In recent decades, distributed fibre-optic sensing (DFOS) has gained notable attention for monitoring geotechnical structures and for use in geophysical studies ${ }^{152-157}$. In this approach, a fibre-optic cable and light waves are the sensor and signal carriers, respectively. To measure a change in strain or temperature, DFOS relies on measurements of backscattered light that travels through the core of the fibre and interacts with imperfections within the core associated with changes in the properties of the surrounding medium ${ }^{158}$. DFOS has been used to detect time-dependent compaction of an aquifer system in Shengze, China ${ }^{157}$ and applied to separate the compaction of an aquitard unit from that of the adjacent aquifer in Su-Xi-Chang, China ${ }^{159}$. Although not yet widely used, DFOS is a low-cost tool that can provide pointwise observations of a small system, such as a structure or an aquifer system. More expensive varieties of this technique that can record strain at micrometre-scale precision have become available more recently ${ }^{160}$.

Space-borne methods. Both GNSS and InSAR can be used to measure coastal land subsidence (FIC. 2c). The Global Positioning System (GPS) is the GNSS system that is owned by the US Government and supports positioning, navigation and timing ${ }^{161}$ (FIG. 2c). The first satellite was launched in 1978 and today's constellation includes 32 satellites, orbiting the Earth every $\sim 12 \mathrm{~h}$ $\left(\right.$ REF. $\left.^{162}\right)$. The popularity of GPS for geodetic applications is due to its millimetre-level positioning accuracy, which is achieved by continuously tracking the phase of the carrier signals and either differencing between two nearby stations to remove satellite clock errors or using satellite clock estimates derived from a global network ${ }^{163,164}$. Currently, the International GNSS Service oversees the development of infrastructure for precise positioning at a global scale by distributing precise satellite orbital and clock data and maintaining several data and analysis centres.

FIGURE 3 shows the current distribution of GNSS stations from all sources within $0.75^{\circ}$ of the world's shorelines, colour-coded by their VLM rate, based on solutions processed by the Nevada Geodetic Laboratory ${ }^{165}$. Note that these rates are a lower bound on the present-day subsidence rates in many low-elevation coastal zones where GNSS stations are often anchored at greater depths $(\sim 15 \mathrm{~m})^{87}$ than typical $(1-3 \mathrm{~m})$. Therefore, these stations do not capture the subsidence attributed to processes occurring between the land surface and the anchor depth. A combination of GNSS with an RSET or other measurements of shallow subsidence could provide a complete estimate of the total subsidence rate. Another approach is to use GPS interferometric reflectometry to capture VLM above the foundation of the GPS anchor ${ }^{166}$. Time series and estimated velocities derived from GPS data are available from several analysis centres, including UNAVCO, the Nevada Geodetic Laboratory and, specifically for GPS sites co-located with tide gauges, SONEL.

For nearly three decades, InSAR deformation maps have provided an all-weather, day-and-night monitoring capacity at an unprecedented spatial coverage and resolution ${ }^{167-171}$. Currently, more than 15 synthetic aperture radar (SAR) satellites are in orbit ${ }^{172-174}$. The InSAR technique uses microwave radar signals to illuminate the ground surface and then records the amplitude and phase of the signals backscattered from the surface (FIG. 2C). Comparing the change in the phase of the signal between two SAR images acquired at different times over the same area from two nearby and precisely measured orbital positions enables the displacement of the ground surface towards or away from the sensor (a satellite or aeroplane) to be determined. The precision of the phase observations is often expressed in terms of the coherence between the two SAR images ${ }^{173,175}$, with values close to one indicating high-quality measurements. The phase coherence is a function of several factors ${ }^{176}$, including spatial baseline (the separation between satellite locations at the time of acquisition), temporal baseline (the period between two acquisitions) and thermal noise (due to changes in receiver characteristics). Also, the radar wavelength of the SAR instrument, atmospheric conditions during each image acquisition and land cover can affect the interferometric coherence ${ }^{173,177}$. For example, the coherence decreases as the baseline increases, but the rate of decrease is slower for longer wavelengths $(\lambda)$, such as $L$ band $(\lambda=235 \mathrm{~mm})$ versus $C$ band $(\lambda=56 \mathrm{~mm})$ and 


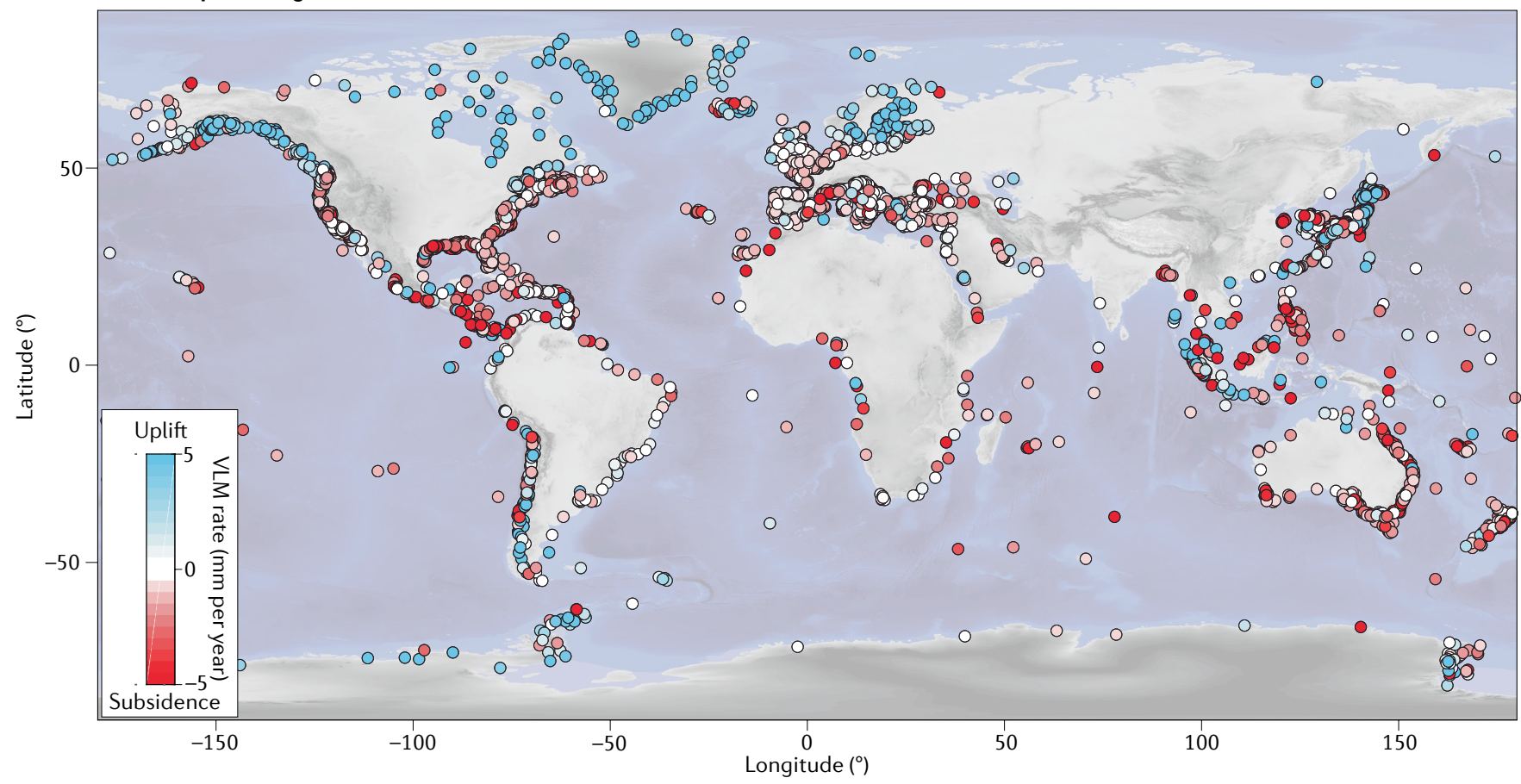

Fig. 3 | Worldwide observations of coastal land subsidence. The estimated rate of land subsidence at coastal areas observed by using global navigation satellite system networks within the IGS14 reference frame ${ }^{165}$. An improvement over earlier realizations ${ }^{278}$, the parameters of the IGS14 frame are of higher accuracy, which yields a more accurate estimate of the long-term land-subsidence rate. Note that these rates are likely a lower bound on the actual subsidence rate in several cases, owing to the absence of shallow signals. VLM, vertical land motion.

$\mathrm{X}$ band $(\lambda=31 \mathrm{~mm})$. Interferometric phase coherence substantially decreases over densely vegetated areas, for which the longer-wavelength L-band data generally yield higher coherence than C-band and X-band data. Moreover, changes in properties of the propagation medium (such as pressure, temperature and humidity, and total electron content) between the two acquisitions cause an additional phase contribution that does not affect the phase coherence but can be misinterpreted as phase delay due to VLM. Several remedies have been developed to overcome the limitations of InSAR (BOX 1).

Challenges. There are several challenges associated with obtaining VLM measurements suitable for studying RSL rise. The first and likely main challenge is to obtain these measurements in a global reference frame. Subsidence measurements from InSAR, RSETs, DFOS and extensometers are inherently provided in a local reference frame, whereas observations of VLM gathered from repeated geodetic levelling surveys and GNSS are referenced to a regional or global reference system (the ellipsoid in the case of GNSS and the geoid in the case of levelling). The International Terrestrial Reference Frame ${ }^{178}$ provides a geocentric reference frame for GNSS and other space-based techniques and motions measured through InSAR, levelling or other methods that can be linked to this reference frame through regional GNSS networks. The use of a geocentric global reference frame is essential for measuring quantities such as GMSL and allows for comparison between different sites along the coast. However, regional reference systems can be sufficient to measure spatial variations in VLM. The geocentre is the natural origin for a global frame, and such a definition makes it possible to determine whether a given location is rising or falling relative to the centre of the Earth. Therefore, levelling and GNSS observations are needed to link together locally referenced measurements. Levelling measures changes in height with respect to the gravity field (that is, the geoid) and is traditionally referenced to a mean sea-level datum. This datum would approximate the sea surface if it extended under the continents ${ }^{140}$, with the origin of that datum linked to one or more tide gauges to provide a sea-level reference. GNSS, however, is a purely geometric technique and measures geometric heights with respect to a nongravitational reference frame (FIG. 2c). Thus, the combination of GNSS and levelling heights must also account for temporal and spatial $(\sim 0.7 \%)$ variations in the gravity field. GNSS observations, such as those shown in FIG. 3, are used to establish a global network of benchmarks on land. Spatial variation in VLM can be measured directly by differencing the observed motions of GNSS sites or of pixels within an InSAR-derived displacement map. However, these data need to be referenced to a global geocentric frame, such as the International Terrestrial Reference Frame, to determine absolute motions that can be compared with changes in the sea surface.

Defining the relationship between a non-gravitational reference frame (that is, the ellipsoid used for GNSS observations) and the geoid (suitable for sea-level studies) is challenging. Geometric heights are typically referenced to the best-fitting ellipsoid of revolution that 
approximates the geoid ${ }^{140,141}$. However, the ellipsoid differs from the geoid by up to $\sim 100 \mathrm{~m}$ (FIC. 2). Nevertheless, rates of VLM measured relative to the ellipsoid or geoid can be combined, as long as the geoid-ellipsoid separation remains constant in time (or changes are accounted for). Changes in the geoid-ellipsoid separation result from changes in the gravity field associated with large-scale mass redistributions, mainly GIA.

In summary, to monitor coastal subsidence, various observation techniques should be used in concert, as exemplified by a 'subsidence superstation' that began operating in the Mississippi Delta in 2016 (REF. ${ }^{179}$ ) and that currently includes an RSET, GNSS and optical-fibre strainmeters ${ }^{160}$, along with detailed stratigraphic analysis of the study site. GNSS data (corrected for shallow subsidence signals) and InSAR observations should be combined to establish a global reference system and densify observations of VLM so that this spatially variable term in RSL rise is known ${ }^{97,180}$. Thus, there is an immediate need to develop frameworks that rigorously combine spatially dense SAR interferometric line-of-sight observations with measurements of the $3 \mathrm{D}$ displacement field at sparse GNSS networks to obtain an accurate measurement of VLM at management-relevant resolution that is, the minimum resolution (on the order of $10^{1} \mathrm{~m}$ ) needed for the development of hazard-management strategies - within a stable reference system. This framework must be able to account for the observation and reference-frame errors, and include a mechanism to propagate these errors to the final estimate of VLM and provide the associated uncertainties in the form of the formal variance-covariance matrix.

\section{Modelling land subsidence}

Various models are used to investigate the mechanisms that drive land subsidence, to project forward the contemporary observations of subsidence rates and to obtain future estimates of VLM. In this section, we

\section{Box $1 \mid$ InSAR advances}

Loss of coherence can limit the coastal areas for which conventional interferometric synthetic aperture radar (InSAR) can provide useful data. To overcome this limitation, one approach is to install corner reflectors in coastal wetlands ${ }^{282}$, as has been done in marshes in the Venice Lagoon, Italy. Multitemporal InSAR approaches, which combine several synthetic aperture radar (SAR) acquisitions, have also been developed to overcome some of the limitations of conventional InSAR. These multitemporal approaches exploit large sets of SAR images acquired over the same area with a similar viewing geometry $167,169,170,283-285$. Most InSAR time series algorithms either implement a suite of filters to mitigate the impact of atmospheric delay on the obtained deformation time series and velocity ${ }^{167,169,285,286}$ or apply models informed by external data sets ${ }^{287-289}$.

InSAR observations are 1D measurements of surface deformation in the line-of-sight direction ${ }^{175}$. To obtain an estimate of subsidence - that is, deformation in the nadir direction - several approaches have been proposed to combine line-of-sight observations with other data sets to generate maps of the 3D displacement field ${ }^{290}$. For measurements of coastal subsidence, the goal of these methods is to distinguish vertical from horizontal motions ${ }^{97}$. These supplementary data sets include azimuthoffset measurements ${ }^{291-293}$, the direction of the displacement field ${ }^{294-296}$ and global navigation satellite system observations ${ }^{97,297,298}$. In summary, to obtain high-resolution estimates of spatially and temporally variable subsidence at the precision and accuracy desired for studies of relative sea-level rise and flooding hazards, it is necessary to integrate observations from various SAR satellites with those obtained from global navigation satellite system stations. The increased redundancy improves the ability to adjust errors, yielding more accurate results. discuss several of these models and assess how reliably contemporary rates of motion can be projected forward in time.

To model the earthquake cycle, elastic ${ }^{181,182}$ and viscoelastic ${ }^{48,183}$ models are used, which relate the slip on the plate-boundary fault to the observed land subsidence ${ }^{48,52}$. Although these inverse models for coseismic slip can have non-unique solutions because of poor model resolution offshore ${ }^{184}$, they are usually quite good at predicting the VLM at the shoreline, as long as there are nearby data on land ${ }^{185}$. Additional constraints on the rate of land subsidence at subduction zones are provided through palaeoseismic and palaeo sea-level studies ${ }^{185-187}$. Although it is not possible to predict the slip distribution of future earthquakes, it might be possible to make probabilistic projections based on the record of the slip during past earthquakes.

FIGURE 1a (and REF. ${ }^{188}$ ) shows an example of model predictions for the interseismic and coseismic vertical displacements for a hypothetical subduction zone ${ }^{182,189}$, using a fault buried in an elastic, isotropic, half-space medium. In many places, the downdip end of the interseismic locked region and the downdip end of the coseismic rupture are located close to the shoreline; therefore, the most common pattern along the coast is steady interseismic uplift, punctuated by abrupt subsidence during earthquakes, as vividly demonstrated during the 1960 Chile and 1964 Alaska earthquakes ${ }^{190}$. The opposite pattern can occur when the locked region extends well inland from the coast, for example, along the central Chilean coast ${ }^{49,191,192}$ and at the Nicoya Peninsula of Costa Rica ${ }^{193,194}$. Many large subduction earthquakes are followed by additional postseismic uplift at the coast, due to afterslip on the fault zone and viscoelastic relaxation of the mantle ${ }^{195,196}$. Although it is not possible to predict the time of the next major subduction earthquake with any certainty, it is possible to project the first-order ongoing spatial and temporal patterns of interseismic VLM preceding that earthquake.

GIA models require the specification of the full loading history, including the effects of gravitationally consistent changes in sea level ${ }^{12,13,77}$. Most studies assume a 1D layered viscoelastic Earth model, with an ice history constrained mainly by mapped ice-sheet extents and RSL histories along palaeoshorelines. FIGURE 4 a shows the predicted present-day uplift and subsidence rates across North America for one such model: the ICE-6G_C ice model with the VM5a Earth model ${ }^{197}$. The pattern of vertical motion and RSL rise is intricate during and immediately after deglaciation for several reasons, including migration of the collapsing forebulge as the ice sheet dissipates and competition between rebound and the barystatic sea-level rise. As a result, RSL histories near the ice margin tend to feature periods of falling and rising RSL over time ${ }^{198}$, while far from the ice sheet, the barystatic sea-level rise dominates the signal.

The timescales for these variations depend on the extent of the load and the relaxation times of the viscoelastic layers; for large continental ice sheets, the pattern in FIG. 4 a will remain steady for centuries, as the relevant mantle-relaxation times are on the order of $10^{3}$ years. Disagreements between competing models 

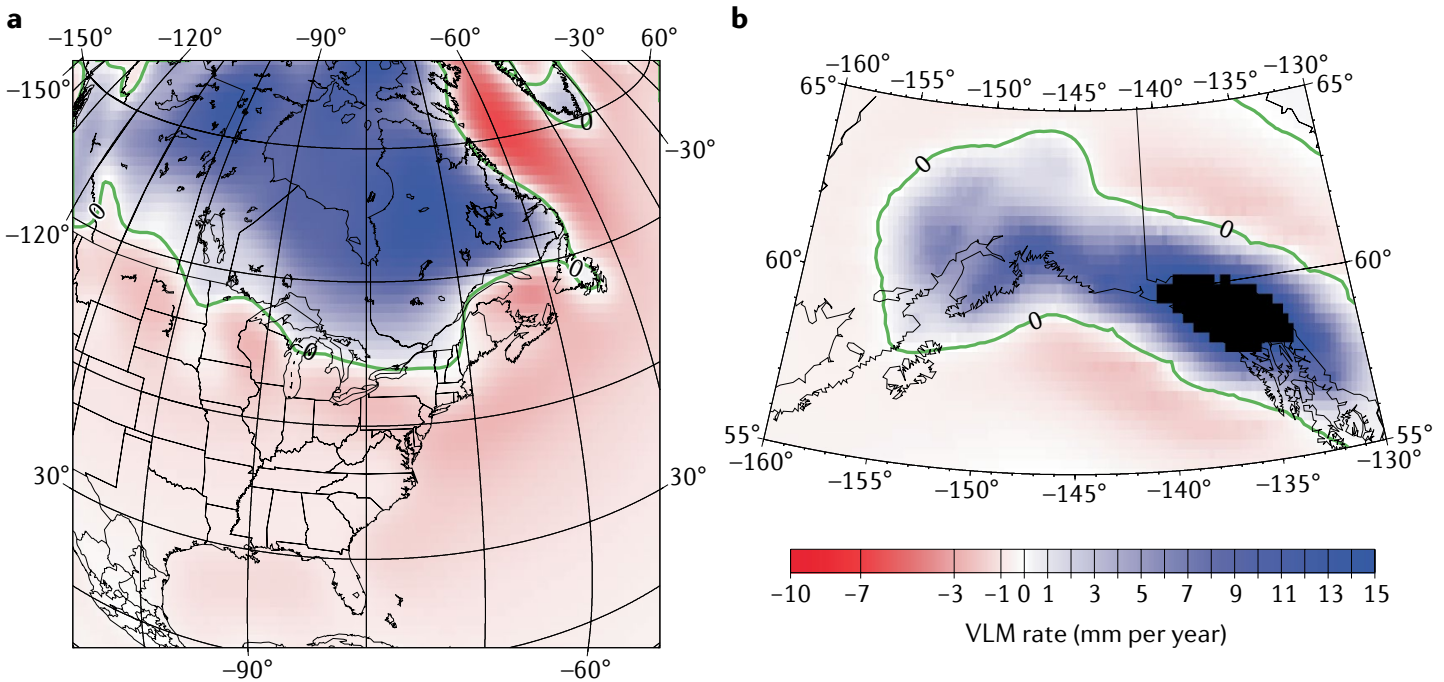

Fig. 4 | Modelling vertical land motion. a | Vertical velocity predictions from the ICE-6G_C glacial isostatic adjustment model and VM5a Earth model across North America. Blue indicates uplifting regions and red subsiding regions (note that the colour scale is not linear for the subsiding regions). The green lines show where the vertical land motion (VLM) due to glacial isostatic adjustment is zero. The subsidence across the eastern United States results from the ongoing collapse of the proglacial forebulge. $\mathbf{b}$ | Vertical velocity predictions for southern Alaska from the model of REF. ${ }^{203}$, with the same colour scale as panel a. Uplift in southern and southeast Alaska is caused by ongoing and recent deglaciation over the past 100-200 years. The colour scale for uplifting regions is saturated, and peak uplift rates in Alaska exceed $30 \mathrm{~mm}$ per year.

are mainly due to differences in assumed ice histories, the lithospheric thickness and the mantle-viscosity structure, including the effect of lateral variations in viscosity. Therefore, 3D Earth models are increasingly considered $^{199-201}$, as well as probabilistic approaches to loading, owing to uncertain ice-sheet histories ${ }^{200,202}$. Regions with recent or ongoing deglaciation will experience additional VLM not accounted for in the example of FIG. 4a. In areas with mantle viscosities typical of continental shields, such as Greenland, mantle-relaxation times are long, and, thus, the present-day ice losses are usually treated as an elastic load change and computed separately from the viscoelastic effects ${ }^{76}$. In areas of low mantle viscosity, such as south-east Alaska ${ }^{77,203}$, Patagonia ${ }^{204,205}$, Iceland ${ }^{206}$ or the Antarctic Peninsula and West Antarctica ${ }^{75,207}$, a full viscoelastic computation including the load history over the past few decades to centuries is required because the relaxation times can be on the order of decades. The pattern of displacements for ongoing and recent deglaciation is similar to that shown in FIG. $4 \mathrm{~b}$ for Alaska, with uplift in the areas of current or recent mass loss. Uplift rates, however, can be as high as several tens of millimetres per year in regions of rapid ice loss, much greater than the rates attributed to GIA from the postglacial continental deglaciation. As the underlying physics is the same, SIA modelling follows the same principles as used for GIA; studies ${ }^{80,83}$ show that subsidence rates in major depocentres might be non-negligible and on the same order of magnitude as GIA.

Compaction of aquifer systems and hydrocarbon reservoirs has been investigated using rheological models that invoke elastic, plastic and viscous rheologies for a solid medium, or a combination of them ${ }^{208-210}$; models addressing the solid-fluid interaction through 1D consolidation ${ }^{109,211-213}$; or fully coupled
3D models ${ }^{110,214-216}$. The first regional numerical model to simulate and predict coastal subsidence following groundwater extraction from an aquifer system was developed in the early 1970s for the city of Venice, Italy ${ }^{217,218}$, using a combination of 3D finite element flow and a $1 \mathrm{D}$ vertical subsidence model. Subsequent developments accounted for variable compressibility ${ }^{219}$, stress-dependent parameters ${ }^{220}$, changing interbed storage $^{221}$ and the effect of viscosity ${ }^{222}$.

State-of-the-art poromechanical models account for the two-way coupling between solid and fluid, in which a change in the applied stress produces a change in fluid pressure, resulting in a change in the volume and mechanical properties of the porous medium ${ }^{110}$. As fluid mass changes following pumping, it creates a differential pore pressure, which drives fluid flow ${ }^{223}$ and modifies the stress field, causing deformation of the porous medium. The time dependence of fluid-pressure diffusion results in time-varying pore pressure, poromechanical stress and strain $^{110,224}$. The role of geomechanics in land subsidence due to groundwater extraction and injections is further discussed in REF. ${ }^{101}$. Additionally, timedependent viscous deformation of the porous medium, so-called creep (whereby the porous medium changes volume gradually at constant effective stress), often governs subsidence in strata underlying artificially made structures ${ }^{225-228}$. Anthropogenic VLM due to fluid extraction and injection can be modelled using several available codes based on both finite differences and finite elements, which invoke elastic, elastoplastic or visco-elasto-plastic rheologies ${ }^{99,106,119,229-235}$.

Groundwater level and compaction within the Shanghai aquifer system in China, comprising five confined aquifers (numbered sequentially from shallow to deep) underlying a shallow unconfined aquifer, 
are monitored by 27 extensometer groups and more than 1,400 observation wells, some dating back to the $1960 \mathrm{~s}^{210}$. During the period 1949-1968, principally the second and third confined aquifers were exploited, and the yearly rate of subsidence during 1957-1961 was as high as $110 \mathrm{~mm}$ per year. Ensuing restrictions on groundwater extraction reduced subsidence during the 1970s to the mid-1980s. Subsequently, increased groundwater extraction from deeper aquifers led to increased compaction, particularly in the fourth confined aquifer. FIGURE 5 a shows observations of the groundwater level and compaction of the fourth confined aquifer during the early 1980s to 2003 (REF. ${ }^{210}$ ). The observations are characterized by an annual cycle and a distinct period of decreased compaction and groundwater-level decline during the 1980 s, followed by a period of increased compaction and groundwater-level decline. A double-yielding visco-elasto-plastic model performs well in simulating the temporally variable compaction of the aquifer unit and associated groundwater level ${ }^{210}$.

Natural hydrodynamic compaction of coastal sediments due to sediment loading can be modelled using a set of constitutive equations similar to those used for modelling aquifers and reservoirs ${ }^{93}$. There are several compaction-fluid flow models in the literature ${ }^{91,236-238}$. For example, a 1D model was used to establish an approximate relationship between the compaction of deep, pre-Holocene basin sediments (interbedded sand and mud at 50-700 $\mathrm{m}$ depth) and variable sediment loads in the Rhine-Meuse Delta ${ }^{93}$. This study demonstrated the importance of hydrodynamically delayed (that is, delayed dissipation of fluid overpressure within the subsurface) compaction for sedimentary basins, with subsidence rates of $>1 \mathrm{~mm}$ per year under favourable conditions. Using a novel numerical model that accounts for large compaction rates and the delayed pore-fluid equilibration ${ }^{238}$, it was possible to attribute contemporary shallow (top $\sim 20 \mathrm{~m}$ ) compaction rates of several centimetres per year in the mud-dominated strata of the Mekong Delta to delayed natural compaction of Holocene deltaic deposits ${ }^{19}$.

Modelling coastal subsidence is a challenging task, owing to the contribution of various intertwined processes $^{27,124,195,196}$. Thus, there is a need to invoke a wide range of mechanical models and rheologies to explain observations. Often, more than one mechanism affects observations at a given site. For example, a place on the Cascadia coast that usually experiences some uplift during the interseismic period ${ }^{165}$ might experience subsidence owing to the rapid compaction of aquifers caused by groundwater overdraft (generally, groundwater extraction in excess of groundwater recharge). In coastal Louisiana, depending on the location, the observed VLM results from a combination of dominant shallow sediment compaction, plus GIA, SIA, hydrocarbon extraction and, possibly, growth faulting ${ }^{34,56,64,81,200,239}$. In these cases, and to explain the observation of land subsidence, elastic or viscoelastic models of fault slip should be combined with visco-elasto-plastic models of sediment and aquifer-system compaction. A 2016 community paper ${ }^{179}$ highlighted the need for integrated models. However, in such models, parameters are often correlated, and their relationship to observations can be highly nonlinear.

\section{Projections of land subsidence}

Future projections of land subsidence are required for forecasting RSL rise and flooding hazards through the twenty-first century.

Sea-level projections are incorporated into US statewide or regional resilience plans, such as the Texas Coastal Resiliency Master Plan ${ }^{240}$ and the US National Climate Assessment. Projections of future sea-level rise and its effects have been generated in several regions, such as the US West Coast ${ }^{241}$, the Chesapeake Bay ${ }^{242}$ and coastal Louisiana ${ }^{243}$. GIA models not only explain why, for example, the sea level is rising faster in the Chesapeake Bay region than in Florida but can also project the GIA-driven amount of RSL rise by the year $2100\left(\right.$ REF. $\left.^{200}\right)$. However, both geological and geodetic VLM data show substantial variation in subsidence in the Chesapeake Bay region ${ }^{244}$ at a spatial scale far smaller than that of the tide-gauge network ${ }^{245}$, and any VLM signals that are not adequately sampled by the available tide gauges will be missed in current projections. For example, projections for several sinking cities, such as Jakarta (Indonesia) ${ }^{246}$, Ho Chi Minh City (Vietnam) $)^{120}$ and Manila (Philippines) ${ }^{247}$, would miss the rapid, localized subsidence now observed using InSAR (mostly caused by groundwater extraction). A notable exception to this is the Houston-Galveston region ${ }^{248}$, where subsidence monitoring, principally by the Harris-Galveston Subsidence District, has been conducted for decades, and the impact of historical and future subsidence on inland and coastal flooding, as well as RSL rise, can be better constrained.

Future projections of VLM related to plate-boundary earthquakes are challenging, owing to the unpredictability of earthquakes. FIGURE $5 b$ shows the simulated VLM due to the earthquake cycle at Washington's Olympic Peninsula, USA, where the long-term uplift rate is $\sim 2 \mathrm{~mm}$ per year; the gradual uplift leading up to the earthquake abruptly shifts to subsidence during the event. Knowing when gradual uplift turns into rapid subsidence requires predicting the time of the megathrust earthquake ${ }^{135}$, although the interseismic uplift is expected to remain reasonably constant until that time. The rates of interseismic uplift and coseismic subsidence vary along the length of the subduction zone based on factors that influence fault slip, such as the geometric complexity of the plate interface ${ }^{249,250}$ and the frictional strength of the fault-zone material, which, in turn, depends on lithology $y^{251,252}$, temperature ${ }^{253}$ and pore-fluid pressure ${ }^{254-256}$. Estimates of contemporary surface deformation can constrain kinematic models of interseismic deformation $^{48}$ that allow VLM rates to be forecasted throughout the twenty-first century. These forecasts will have to be augmented by a range of scenarios to simulate VLM, owing to the variability in magnitude and distribution of potential coseismic displacements (and postseismic effects). For these scenarios, one can use estimates of maximum coseismic offset based on historical or geological records $\mathrm{s}^{257}$ and interseismic deformation models ${ }^{258}$. 
a Aquifer compaction in Shanghai, China

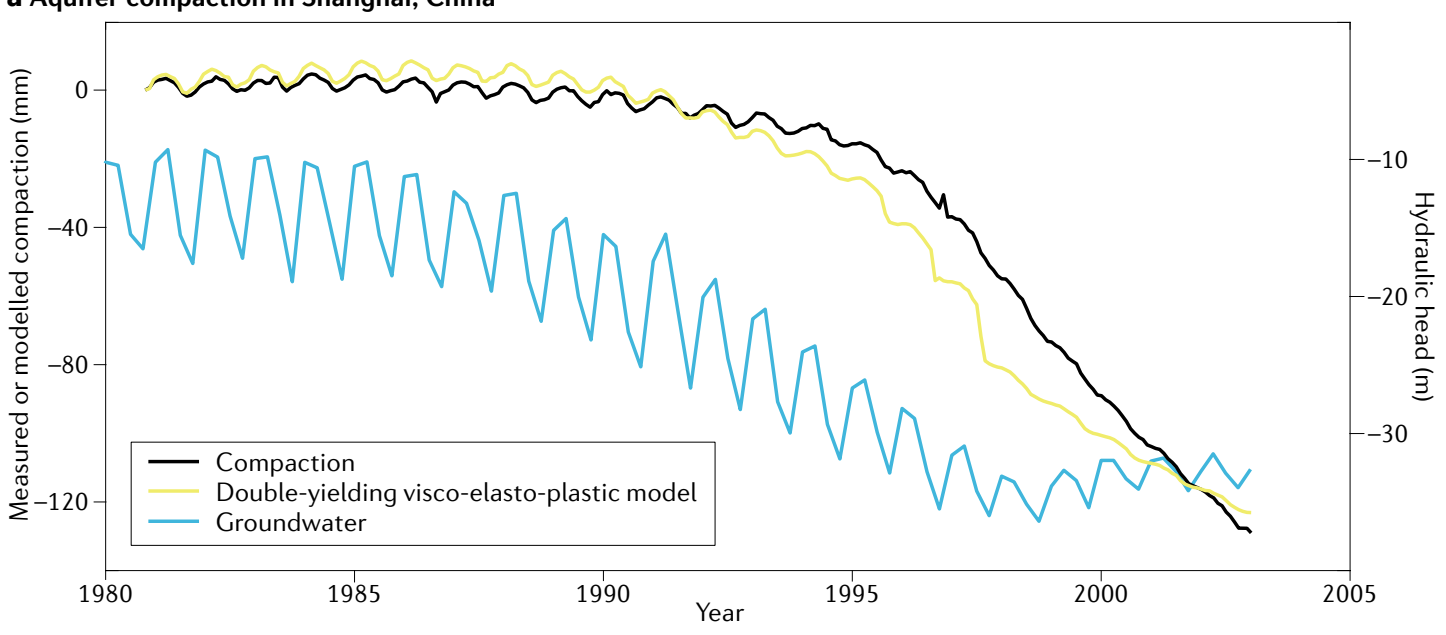

b Vertical land motion due to earthquake cycle

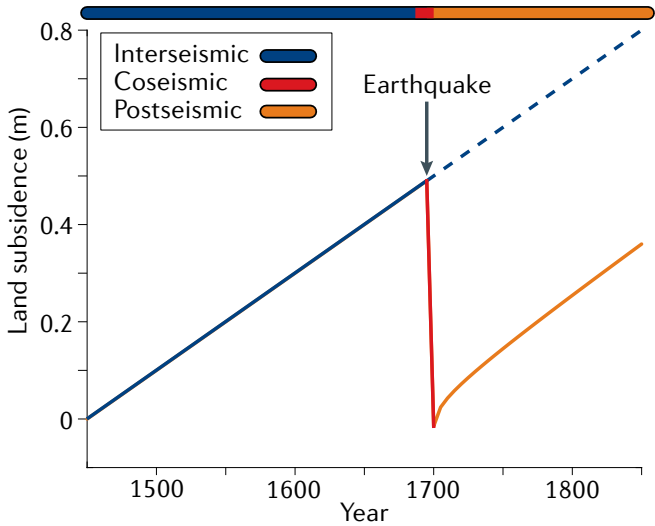

c Land subsidence due to aquifer-system compaction

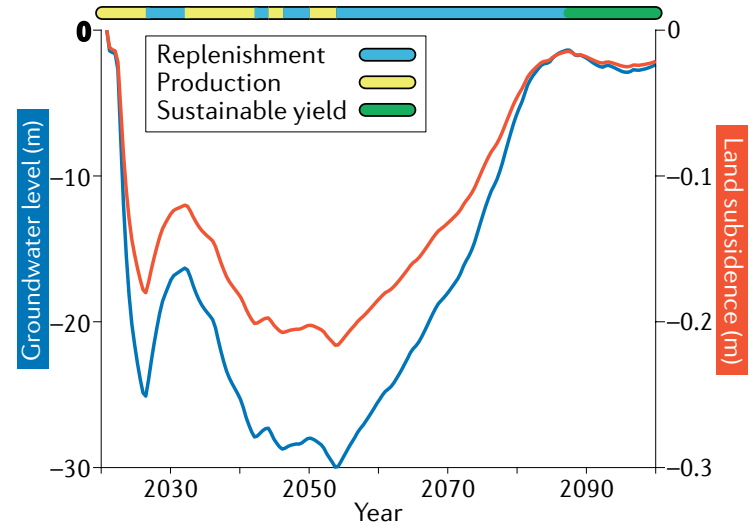

d Predicting aquifer-system compaction in Yuanchang, Taiwan

Normal precipitation

Low precipitation

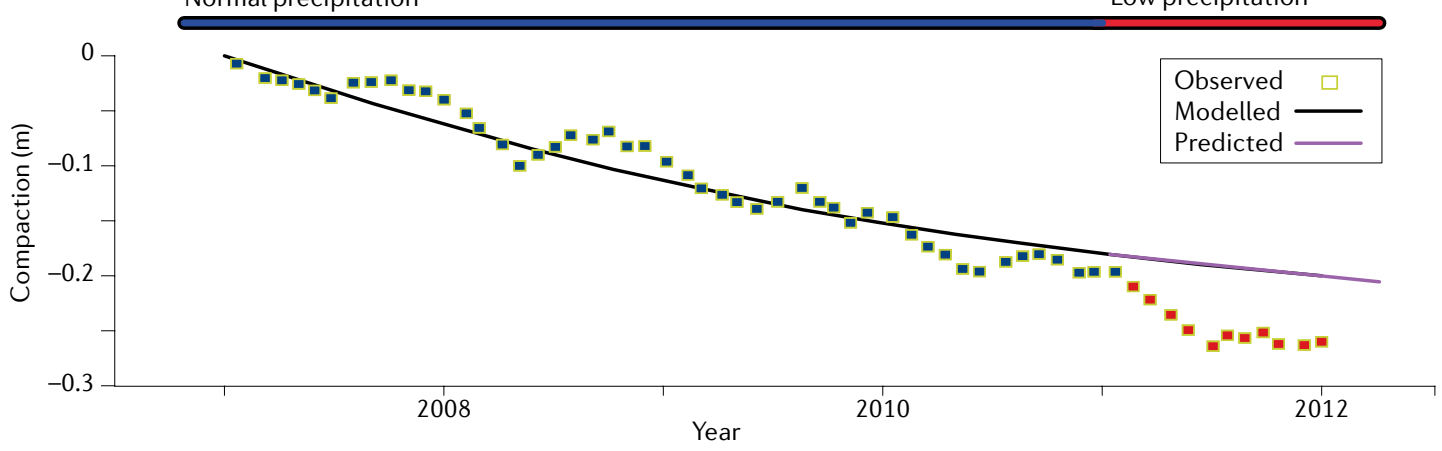

The contemporary rate of GIA can be as high as a few millimetres per year outside formerly glaciated areas, and GIA from the deglaciation of continental ice sheets can be considered near steady over a century ${ }^{73,74}$. In areas undergoing present-day deglaciation, the rates and detailed spatial patterns of uplift will be more difficult to project, as they will depend on future ice-load changes. Greenland provides an excellent example because the mass loss has accelerated dramatically since the 1990s, and the spatial distribution of mass loss has changed over the past two decades ${ }^{76,259-262}$.

Land subsidence owing to aquifer-system and hydrocarbon-reservoir compaction is generally temporally variable and applies to relatively small spatial scales (up to tens of kilometres) ${ }^{25,100,263}$, but may extend over larger areas when widespread extraction is taking place, as seen in the Mekong Delta ${ }^{119}$. For aquifer-system compaction, the subsidence rates can be high, up to hundreds of millimetres per year ${ }^{101,104,105,119,264}$, depending on surface-water supply, freshwater demand and drought conditions $s^{117,118}$. None of these factors are expected to remain constant in the future, which makes this contribution to land subsidence highly unpredictable; future changes in groundwater regulation and socioeconomic factors could also affect projections. Accounting for these uncertainties, projections of anthropogenic subsidence in the Mekong Delta through the twenty-first century have been developed based on plausible extraction scenarios ${ }^{38}$, which can be used to guide policy decisions. 
4 Fig. 5 | Observed, modelled and predicted aquifer-system compaction and vertical land motion due to earthquake cycle. a|Compaction of the fourth confined aquifer unit at $160-240 \mathrm{~m}$ in Shanghai, China, owing to groundwater volume change, and results from a double-yielding visco-elasto-plastic model used to simulate this observation. The time series of the groundwater level is also shown for the same period. $\mathbf{b}$ | Land subsidence and uplift due to the earthquake cycle simulated at the location of the global navigation satellite system station P403 (longitude: $-124.141^{\circ}$, latitude: $48.062^{\circ}$ ) within the Olympic Peninsula, Washington, USA, where the long-term uplift rate is $2 \mathrm{~mm}$ per year. The coseismic land subsidence is assumed to be $0.515 \mathrm{~m}$ for the earthquake in 1700 , which is marked by the arrow ${ }^{33}$. For the postseismic deformation, only an afterslip with a relaxation time of 7 years is considered. c $/$ Simulated scenario in which the Santa Ana Coastal Basin, California, USA, is considered as the reference and land subsidence due to possible variations of groundwater level throughout the twenty-first century is calculated, using the code in $\mathrm{REF}^{279}$. $\mathbf{d}$ | The observed land subsidence at Yuanchang, Taiwan, the subsidence simulated using a nonlinear poroelastic model and the predicted land subsidence during 2011 using the model calibrated for 2007-2010 (REF. ${ }^{267}$ ). Panel a adapted from REF. ${ }^{210}$, Springer Nature Limited. Data for panel $\mathbf{b}$ from the P403 station. Panel $\mathbf{d}$ adapted from REF. $^{267}$, Springer Nature Limited. which different projections of recharge rates are used to estimate aquifer-compaction rates.

Contributions to land subsidence from natural compaction of shallow sediments in response to loading can also show considerable spatial variation, depending on local sedimentary architecture and accretion rates ${ }^{34,96,238}$. Thus, employing an existing compaction model that is calibrated using observations (preferably both contemporary and geological) may enable projection into the future $^{19}$. However, the loading conditions (for example, accretion rate and sediment type) could change over time, and, thus, compaction rates might not remain steady. Moreover, to model natural sediment compaction separately, the observed VLM first needs to be corrected for other contributions (such as contemporary rates of GIA, SIA and fluid extraction), although some of these corrections may be small.

FIGURE $5 c$ shows a simulated scenario highlighting the potential elastic behaviour of an aquifer, similar to that of the Santa Ana Coastal Basin in California ${ }^{265}$, in which the groundwater table declines by as much as $30 \mathrm{~m}$ until 2055 and then rises to the initial level by 2085, owing to variable pumping and replenishment of the aquifer system. The associated land subsidence of as much as $200 \mathrm{~mm}$ is simulated using a poroelastic $\operatorname{model}^{266}$. The land subsidence closely follows the pattern of groundwater-level change, and the deformed aquifer system rebounds to almost its original thickness with groundwater recharge. FIGURE $5 d$ shows data from an aquifer in Yuanchang, Taiwan ${ }^{267}$, which compacted $\sim 250 \mathrm{~mm}$ between 2007 and 2012. A nonlinear poroelastic model was calibrated using observed compaction during 2007-2011 (a period of normal precipitation) to predict compaction in 2011-2012. Model predictions were not successful, partly because 2011-2012 was a dry year with reduced groundwater recharge and increased groundwater pumping, and, thereby, increased subsidence. The model calibrated for a period of normal precipitation, therefore, underestimated the subsidence.

Projections of the effects of aquifer-system and hydrocarbon-reservoir compaction can be simulated with appropriate poromechanical models and calibrated using contemporary observations of VLM. However, a crucial question is how key model boundary conditions (that is, rates of fluid extraction and natural recharge) will vary over the twenty-first century. Current climate models predict that droughts will become more intense and frequent in parts of the world, leading to decreases in surface-water availability and natural recharge, as well as increased demand for groundwater ${ }^{268}$. Some studies have assessed the effect of climate change on groundwater resources through its impact on projections of net recharge under different warming scenarios ${ }^{269-272}$. Despite their usefulness for understanding groundwater and surface-water availability throughout the twenty-first century, such models currently do not provide adequate spatial resolution to be used for investigating the deformation of individual coastal aquifers. Nevertheless, they are a good source of information for generating an ensemble of scenarios in

\section{Future perspectives}

The frequency of flooding is projected to double across most US shorelines with just $100-200 \mathrm{~mm}$ of local RSL rise $^{273}$ - levels that could be reached by mid-century under most GMSL projections. Accounting for land subsidence will result in these thresholds being exceeded sooner than projected based on GMSL rise only (FIG. 6a), whereas local uplift would cause them to be reached later. Although individual flooding events will be triggered by storm surges or higher-than-normal tides, the long-term trend due to the combination of GMSL rise and land subsidence will change the probability of flooding over time, in most cases, resulting in an increased hazard.

Worldwide, more than 600 million people live in low-lying, flood-prone coastal areas $(<10 \mathrm{~m})^{1}$, but is projected to surpass 1 billion this century ${ }^{2}$. The future flood risk to these communities is mainly controlled by the rate of RSL rise $e^{29,97,274}$. Future inundation-hazard maps for the San Francisco Bay Area (FIG. 6b,c) show that sea-level rise alone poses a considerable inundation hazard to coastal urban areas and infrastructure, as well as ecologically valuable wetland $\mathrm{s}^{275}$. Considering the likely ranges of various sea-level-rise scenarios and VLM, it was estimated that, in the year 2100, an area of $98-218 \mathrm{~km}^{2}$ would be affected by RSL rise in the Bay Area $^{97}$. The corresponding values for the case of sealevel rise only are in the range $51-168 \mathrm{~km}^{2}$. Even if sea-level rise was halted entirely, VLM alone would place $45 \mathrm{~km}^{2}$ at risk. The contributions of VLM and sea-level rise are clearly evident in the estimated inundation of the San Francisco International Airport (FIG. 6c).

In an era in which climate change and sea-level rise pose unprecedented threats to coastal populations and ecosystems, Earth observation data, such as those provided by InSAR and GNSS, will be essential to inform policy decisions ${ }^{40}$. Although Earth observation data with global coverage are publicly available, and it is technologically feasible to compute high-resolution maps of coastal VLM rates from combined analysis of GNSS and InSAR data ${ }^{97,180}$, this remains computationally demanding. Thus, to date, only limited areas have spatially extensive maps of coastal subsidence with respect to a global reference frame at management-relevant resolution $\left(\sim 10^{1} \mathrm{~m}\right)$. Furthermore, land-based subsidence 


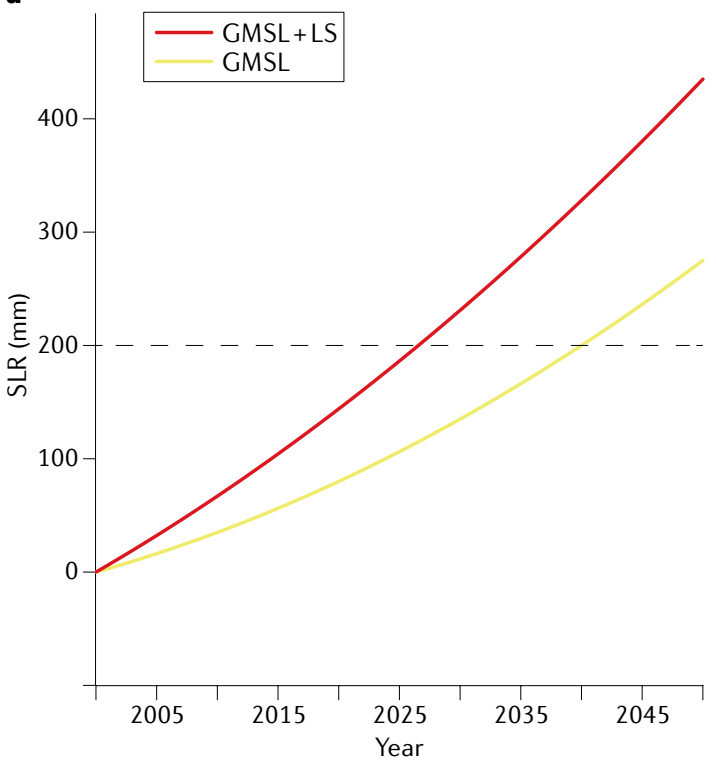

b

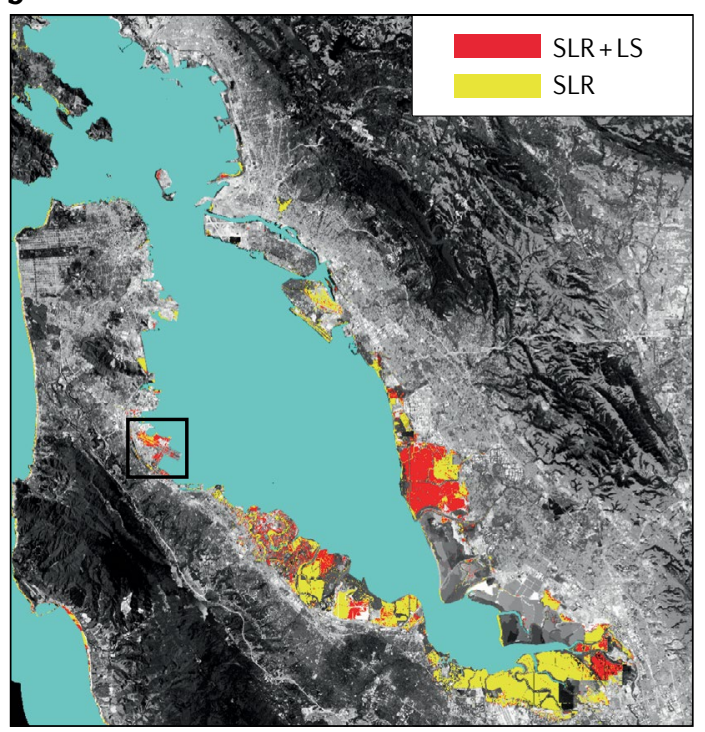

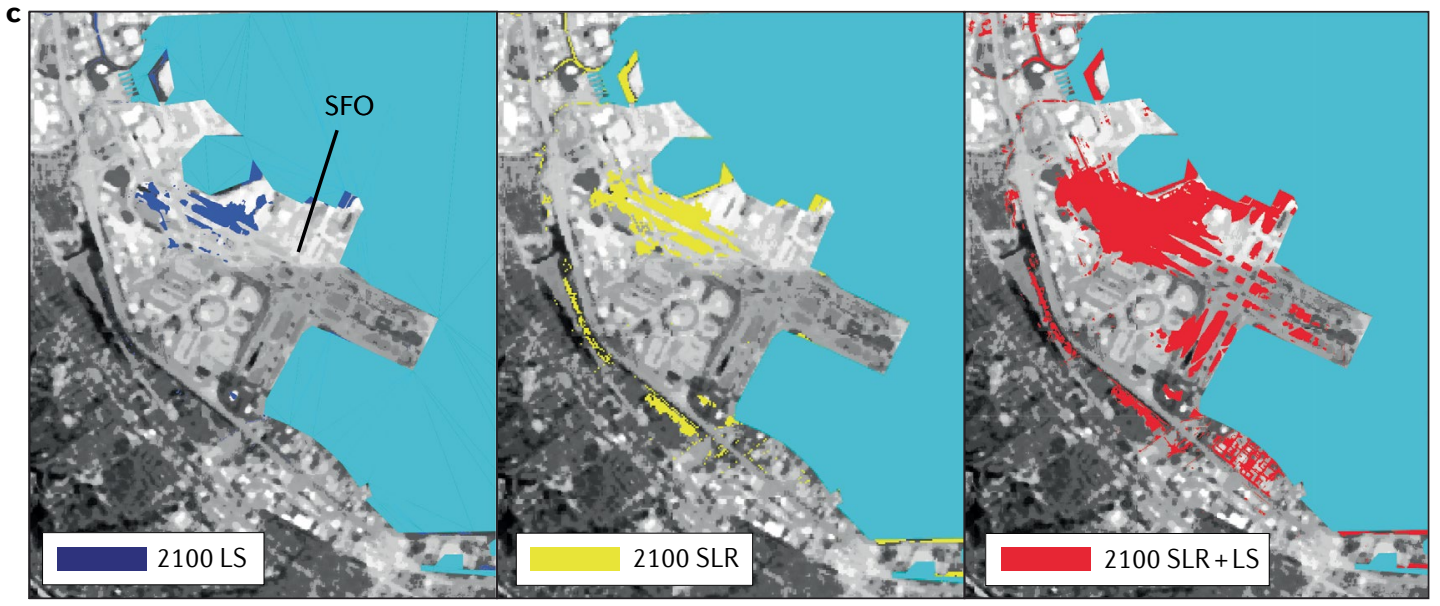

Fig. 6 | Impact of land subsidence on coastal inundation. a | Global mean sea-level (GMSL) rise during the first half of the twenty-first century at the location of the Galveston tide gauge (Texas, USA) ${ }^{280}$ and the GMSL rise adjusted for $3.2 \mathrm{~mm}$ per year of land subsidence (LS). The black dashed line indicates the projected sea-level rise (SLR) threshold at which the frequency of flooding will double across US shorelines ${ }^{273}$. b | Inundation in the San Francisco Bay Area (California, USA) by 2100 , projected by combining LS observations at $\sim 100-\mathrm{m}_{\text {resolution }}{ }^{97}$, projections of SLR throughout the twenty-first century ${ }^{281}$ and high-resolution topographic data ${ }^{5}$. Maps of the potential inundation due to SLR alone and that due to a combination of LS and SLR for the upper bound of the likely range of the Representative Concentration Pathway 8.5 scenario (SLR of $1.04 \mathrm{~m}$ by 2100) are shown. The black box indicates the location of the San Francisco International Airport (SFO). c | Projected inundation of SFO by 2100 , accounting for LS, SLR or a combination of both. Data for panel a from REF. ${ }^{280}$. Panels $\mathbf{b}$ and $\mathbf{c}$ modified from REF. ${ }^{97}$, CC BY-NC.

monitoring (such as the RSET method) is crucial to supplement Earth observation data because it can elucidate the depth-integrated nature of subsidence. Understanding where coastal subsidence occurs and its governing process(es) will be vital for devising effective subsidence-mitigation remedies. The availability of process-based numerical models, calibrated with contemporary observations, enables spatially and temporally variable projections of subsidence ${ }^{38}$. Such projections facilitate testing and the development of effective management strategies to mitigate subsidence, such as regulating subsurface fluid extraction and/or, in the case of aquifer-system compaction, implementing artificial recharge or using imported surface-water supplies to reduce groundwater demand. Several examples from inland areas, including the Tucson Valley, Arizona ${ }^{103}$, the Houston-Galveston region, Texas ${ }^{112}$, and the Santa Clara Valley, California ${ }^{112}$, demonstrate successful subsidence-mitigation management efforts.

Future multidisciplinary work is needed to develop multi-objective models that integrate the underlying physical processes with socio-economic and climatic forcing, and are calibrated using contemporary observations of land-subsidence rates to forecast future changes in the rates due to the non-GIA subsidence processes. For such models to be useful for assessing hazards, they need to provide a reasonable forecast of uncertainties not only due to errors in calibration data but also due to 
imperfect models and uncertainties in climate-change scenarios, as well as future water and energy demands.

Finally, it is important to emphasize that the resilience of coastal lowlands does not just depend on sea-level rise and VLM - that is, RSL rise - but also on the ability of these areas to gain elevation through sediment accretion, both clastic and organic. In other words, a longer-term goal is to move away from 'passive submergence' or 'inundation modelling' to an approach that integrates the types of models discussed herein with surface-process models that account for the feedbacks between VLM and sediment dynamics.

Published online 10 December 2020
1. Hauer, M. E. et al. Sea-level rise and human migration. Nat. Rev. Earth Environ. 1, 28-39 (2020).

2. Neumann, B., Vafeidis, A. T., Zimmermann, J. \& Nicholls, R. J. Future coastal population growth and exposure to sea-level rise and coastal flooding-a global assessment. PLOS ONE 10, e0118571 (2015).

3. Milliman, J. \& Haq, B. U. Sea-Level Rise and Coastal Subsidence: Causes, Consequences, and Strategies Vol. 2 (Springer, 1996).

A comprehensive overview that highlights the fact that coastal subsidence is commonly humaninduced.

4. Hanson, S. et al. A global ranking of port cities with high exposure to climate extremes. Clim. Change 104 89-111 (2011).

5. Kulp, S. A. \& Strauss, B. H. New elevation data triple estimates of global vulnerability to sea-level rise and coastal flooding. Nat. Commun. 10, 4844 (2019).

6. Cazenave, A. et al. Global sea-level budget 1993-present. Earth Syst. Sci. Data 10, 1551-1590 (2018)

7. Frederikse, T. et al. The causes of sea-level rise since 1900. Nature 584, 393-397 (2020).

8. Gregory, J. M. et al. Concepts and terminology for sea level: mean, variability and change, both local and global. Surv. Geophys. 40, 1251-1289 (2019) Community paper that standardizes sea-leve terminology, including VLM, in a mathematically rigorous way.

9. Khan, N. S. et al. Inception of a global atlas of sea levels since the Last Glacial Maximum. Quat. Sci. Rev. 220, 359-371 (2019).

10. Syvitski, J. P. et al. Sinking deltas due to human activities. Nat. Geosci. 2, 681-686 (2009).

11. Farrell, W. \& Clark, J. A. On postglacial sea level. Geophys. J. Int. 46, 647-667 (1976)

12. Kendall, R. A., Mitrovica, J. X. \& Milne, G. A. On post-glacial sea level-II. Numerical formulation and comparative results on spherically symmetric models. Geophys. J. Int. 161, 679-706 (2005).

13. Peltier, W. Global glacial isostasy and the surface of the ice-age Earth: the ICE-5G (VM2) model and GRACE. Annu. Rev. Earth Planet. Sci. 32, 111-149 (2004).

14. Atwater, B. F. Evidence for great Holocene earthquakes along the outer coast of Washington State. Science 236, 942-944 (1987).

15. Nelson, A. R., Shennan, I. \& Long, A. J. Identifying coseismic subsidence in tidal-wetland stratigraphic sequences at the Cascadia subduction zone of western North America. J. Geophys. Res. Solid Earth 101, 6115-6135 (1996)

16. Cahoon, D. R., Reed, D. J. \& Day, J. W. Jr. Estimating shallow subsidence in microtidal salt marshes of the southeastern United States: Kaye and Barghoorn revisited. Mar. Geol. 128, 1-9 (1995). Pioneering study that shows how the RSET method can be used to calculate subsidence rates within the shallowest subsurface of coastal wetlands.

17. Kaye, C. A. \& Barghoorn, E. S. Late Quaternary sea-level change and crustal rise at Boston, Massachusetts, with notes on the autocompaction of peat. Geol. Soc. Am. Bull. 75, 63-80 (1964).

18. Van Asselen, S., Stouthamer, E. \& Van Asch, T. W. Effects of peat compaction on delta evolution: a review on processes, responses, measuring and modeling. Earth Sci. Rev. 92, 35-51 (2009).

19. Zoccarato, C., Minderhoud, P. S. \& Teatini, P. The role of sedimentation and natural compaction in a prograding delta: insights from the mega Mekong delta, Vietnam. Sci. Rep. 8, 11437 (2018)

20. Gambolati, G. et al. Peat land oxidation enhances subsidence in the Venice watershed. Eos Trans. Am. Geophys. Union 86, 217-220 (2005).

21. Hooijer, A. et al. Subsidence and carbon loss in drained tropical peatlands. Biogeosciences 9 , 1053-1071 (2012)

22. Koster, K. et al. Three-dimensional distribution of organic matter in coastal-deltaic peat: implications for subsidence and carbon dioxide emissions by humaninduced peat oxidation. Anthropocene 22, 1-9 (2018).

23. Schothorst, C. Subsidence of low moor peat soils in the western Netherlands. Geoderma 17, 265-291 (1977).

24. van Asselen, S. et al. The relative contribution of peat compaction and oxidation to subsidence in built-up areas in the Rhine-Meuse delta, The Netherlands. Sci. Total Environ. 636, 177-191 (2018).

25. Galloway, D. L. \& Burbey, T. J. Review: regional land subsidence accompanying groundwater extraction. Hydrol. J. 19, 1459-1486 (2011).

26. Ingebritsen, S. E. \& Galloway, D. L. Coastal subsidence and relative sea level rise. Environ. Res. Lett. 9 091002 (2014).

27. Tosi, L., Teatini, P., Carbognin, L. \& Brancolini, G. Using high resolution data to reveal depth-dependent mechanisms that drive land subsidence: the Venice coast, Italy. Tectonophysics 274, 271-284 (2009).

28. DeConto, R. M. \& Pollard, D. Contribution of Antarctica to past and future sea-level rise. Nature 531, 591-597 (2016).

29. Oppenheimer, M. et al. in IPCC Special Report on the Ocean and Cryosphere in a Changing Climate Ch. 4 (eds Pörtner, H.-O. et al.) 321-445 (IPCC, 2019).

30. Bierkens, M. F. \& Wada, Y. Non-renewable groundwater use and groundwater depletion: a review. Environ. Res. Lett. 14, 063002 (2019).

31. Rehrl, T. \& Friedrich, R. Modelling long-term oil price and extraction with a Hubbert approach: the LOPEX model. Energy Policy 34, 2413-2428 (2006).

32. Bertrand, S. et al. Sedimentary record of coseismic subsidence in Hersek coastal lagoon (Izmit Bay, Turkey) and the late Holocene activity of the North Anatolian Fault. Geochem. Geophys. Geosyst. 12, Q06002 (2011).

33. Hawkes, A. D., Horton, B., Nelson, A., Vane, C. \& Sawai, Y. Coastal subsidence in Oregon, USA, during the giant Cascadia earthquake of AD 1700. Quat. SCi. Rev, 30, 364-376 (2011).

34. Jankowski, K. L., Törnqvist, T. E. \& Fernandes, A. M Vulnerability of Louisiana's coastal wetlands to present-day rates of relative sea-level rise. Nat. Commun. 8, 14792 (2017).

35. Brown, S. \& Nicholls, R. Subsidence and human influences in mega deltas: the case of the GangesBrahmaputra-Meghna. Sci. Total Environ. 527 362-374 (2015)

36. Dixon, T. H. et al. Space geodesy: subsidence and flooding in New Orleans. Nature 441, 587-588 (2006).

37. Mazzotti, S., Lambert, A., Van der Kooij, M. \& Mainville, A. Impact of anthropogenic subsidence on relative sea-level rise in the Fraser River delta. Geology 37, 771-774 (2009).

38. Minderhoud, P., Middelkoop, H., Erkens, G. \& Stouthamer, E. Groundwater extraction may drown mega-delta: projections of extraction-induced subsidence and elevation of the Mekong delta for the 21st century. Environ. Res. Commun. 2, 011005 (2020).

Modelling approach to capture uncertainty of future human-induced subsidence and its effect on RSL rise using extraction scenarios.

39. Aerts, J. C. J. H. et al. Evaluating flood resilience strategies for coastal megacities. Science 344 , 472-474 (2014)

40. Morris, E. P., Gomez-Enri, J. \& van der Wal, D. Copernicus downstream service supports naturebased flood defense use of sentinel earth observation satellites for coastal needs. Sea Technol. 56, 23-26 (2015).

41. Brain, M. J. Past, present and future perspectives of sediment compaction as a driver of relative sea leve and coastal change. Curr. Clim. Change Rep. 2, 75-85 (2016).

42. Higgins, S. A. Advances in delta-subsidence research using satellite methods. Hydrogeol. J. 24, 587-600 (2016).
43. Wöppelmann, G. \& Marcos, M. Vertical land motion as a key to understanding sea level change and variability. Rev. Geophys 54, 64-92 (2016).

44. Allen, M. B., Macdonald, D. I., Xun, Z., Vincent, S. J. $\&$ Brouet-Menzies, C. Early Cenozoic two-phase extension and late Cenozoic thermal subsidence and inversion of the Bohai Basin, northern China Mar. Pet. Geol. 14, 951-972 (1997)

45. Sclater, J. G., Taupart, C. \& Galson, D. The heat flow through oceanic and continental crust and the heat loss of the Earth. Rev. Geophys. Space Phys. 18, 269-311 (1980)

46. Leeper, R. et al. Evidence for coseismic subsidence events in a southern California coastal saltmarsh. Sci. Rep. 7, 44615 (2017)

47. Milker, Y. et al. Differences in coastal subsidence in southern Oregon (USA) during at least six prehistoric megathrust earthquakes. Quat. Sci. Rev. 142, 143-163 (2016).

48. Segall, P. Earthquake and Volcano Deformation. Ch. 2 \& Ch. 3 (Princeton Univ. Press, 2010).

49. Dura, T. et al. Coastal evidence for Holocene subduction-zone earthquakes and tsunamis in central Chile. Quat. Sci. Rev. 113, 93-111 (2015).

50. Dura, T. et al. Subduction zone slip variability during the last millennium, south-central Chile. Quat. Sci. Rev. 175, 112-137 (2017).

A multi-proxy paleoseismic study from the overlap of the 1960 and 2010 Chilean earthquakes that documents a mixed coseismic uplift and subsidence history of the coastline.

51. Fujiwara, O., Fujino, S., Komatsubara, J., Morita, Y. \& Namegaya, Y. Paleoecological evidence for coastal subsidence during five great earthquakes in the past 1500 years along the northern onshore continuation of the Nankai subduction zone. Quat. Int. 397, 523-540 (2016).

52. Govers, R., Furlong, K. P., Van de Wiel, L., Herman, M. $\&$ Broerse, $\mathrm{T}$. The geodetic signature of the earthquake cycle at subduction zones: model constraints on the deep processes. Rev. Geophys. 56, 6-49 (2018).

53. Sawai, Y. et al. Transient uplift after a 17 th-century earthquake along the Kuril subduction zone. Science 306, 1918-1920 (2004).

54. Satirapod C. Trisirisatayawong I., Fleitout, L. Garaud, J. \& Simons, W. Vertical motions in Thailand after the 2004 Sumatra-Andaman Earthquake from GPS observations and its geophysical modelling. Adv. Space Res. 51, 1565-1571 (2013).

55. Brown, L. F. Jr, Loucks, R. G., Trevino, R. H. \& Hammes, U. Understanding growth-faulted, intraslope subbasins by applying sequence-stratigraphic principles: Examples from the south Texas Oligocene Frio Formation. AAPG Bull. 88, 1501-1523 (2004).

56. Karegar, M. A., Dixon, T. H. \& Malservisi, R. A threedimensional surface velocity field for the Mississippi Delta: implications for coastal restoration and flood potential. Geology 43, 519-522 (2015).

57. McClay, K., Dooley, T., Ferguson, A. \& Poblet, J. Tectonic evolution of the Sanga Sanga Block, Mahakam Delta, Kalimantan, Indonesia. AAPG Bull. 84, 765-786 (2000)

58. Shen, Z. et al. Mechanisms of Late Quaternary fault throw-rate variability along the north central Gulf of Mexico coast: implications for coastal subsidence. Basin Res. 29, 557-570 (2017).

59. Edwards, M. B. Growth faults in upper Triassic deltaic sediments, Svalbard. AAPG Bull. 60, 341-355 (1976).

60. Morley, C. K. \& Guerin, G. Comparison of gravitydriven deformation styles and behavior associated with mobile shales and salt. Tectonics 15, 1154-1170 (1996).

61. Thorsen, C. E. Age of growth faulting in southeast Louisiana. GCACS Trans. 13, 103-110 (1963).

62. Vendeville, B. Mechanisms generating normal fault curvature: a review illustrated by physical models. Geol. Soc. London Spec. Publ. 56, 241-249 (1991). 
63. Crans, W., Mandl, G. \& Haremboure, J. On the theory of growth faulting*: a geomechanical delta model based on gravity sliding. J. Pet. Geol. 2, 265-307 (1980).

64. White, N., Jackson, J. \& McKenzie, D. The relationship between the geometry of normal faults and that of the sedimentary layers in their hanging walls. J. Struct. Geol. 8, 897-909 (1986)

65. Back, S., Höcker, C., Brundiers, M. \& Kukla, P. Threedimensional-seismic coherency signature of Niger Delta growth faults: integrating sedimentology and tectonics. Basin Res. 18, 323-337 (2006).

66. Dokka, R. K. The role of deep processes in late 20th century subsidence of New Orleans and coastal areas of southern Louisiana and Mississippi. J. Geophys. Res. Solid Earth 116, B06403 (2011).

67. Frederick, B. C., Blum, M., Fillon, R. \& Roberts, H. Resolving the contributing factors to Mississippi Delta subsidence: past and present. Basin Res. 31, 171-190 (2019)

An assessment of long-term subsidence patterns and rates based on an unprecedented analysis of $>80,000$ industry wells.

68. Conrad, C. P. \& Hager, B. H. Spatial variations in the rate of sea level rise caused by the present-day melting of glaciers and ice sheets. Geophys. Res. Lett. 24, 1503-1506 (1997)

69. Milne, G. A. \& Mitrovica, J. X. Postglacial sea-level change on a rotating Earth. Geophys. J. Int. 133, $1-19$ (1998)

70. Mitrovica, J. X. \& Peltier, W. R. On postglacial geoid subsidence over the equatorial oceans. J. Geophys. Res. Solid Earth 96, 20053-20071 (1991).

71. Spada, G. in Integrative Study of the Mean Sea Level and Its Components 155-187 (Springer, 2017).

72. Whitehouse, P. L. Glacial isostatic adjustment modelling: historical perspectives, recent advances, and future directions. Earth Surf. Dyn. 6, 401-429 (2018).

73. Lidberg, M., Johansson, J. M., Scherneck, H.-G. \& Milne, G. A. Recent results based on continuous GPS observations of the GIA process in Fennoscandia from BIFROST. J. Geodyn. 50, 8-18 (2010).

74. Sella, G. F. et al. Observation of glacial isostatic adjustment in "stable" North America with GPS Geophys. Res. Lett. 34, L02306 (2007).

75. Barletta, V. R. et al. Observed rapid bedrock uplift in Amundsen Sea Embayment promotes ice-sheet stability. Science 360, 1335-1339 (2018).

76. Khan, S. A., Wahr, J., Bevis, M., Velicogna, I. \& Kendrick, E. Spread of ice mass loss into northwest Greenland observed by GRACE and GPS. Geophys. Res. Lett. 37, L06501 (2010).

77. Larsen, C. F., Motyka, R. J., Freymueller, J. T. Echelmeyer, K. A. \& Ivins, E. R. Rapid viscoelastic uplift in southeast Alaska caused by post-Little Ice Age glacial retreat. Earth Planet. Sci. Lett. 237, 548-560 (2005).

78. Sasgen, I. et al. Altimetry, gravimetry, GPS and viscoelastic modeling data for the joint inversion for glacial isostatic adjustment in Antarctica (ESA STSE Project REGINA). Earth Syst. Sci. Data 10, 493-523 (2018).

79. Blum, M. D., Tomkin, J. H., Purcell, A. \& Lancaster, R. R. Ups and downs of the Mississippi Delta. Geology 36, 675-678 (2008)

80. Wolstencroft, M., Shen, Z., Törnqvist, T. E., Milne, G. A $\&$ Kulp, M. Understanding subsidence in the Mississippi Delta region due to sediment, ice, and ocean loading: insights from geophysical modeling. J. Geophys. Res. Solid Earth 119, 3838-3856 (2014).

81. Yu, S.-Y., Törnqvist, T. E. \& Hu, P. Quantifying Holocene lithospheric subsidence rates underneath the Mississippi Delta. Earth Planet. Sci. Lett. 331, 21-30 (2012).

82. Grall, C. et al. A base-level stratigraphic approach to determining Holocene subsidence of the GangesMeghna-Brahmaputra Delta plain. Earth Planet. Sci. Lett. 499, 23-36 (2018).

83. Karpytchev, M. et al. Contributions of a strengthened early Holocene monsoon and sediment loading to present-day subsidence of the Ganges-Brahmaputra delta. Geophys. Res. Lett. 45, 1433-1442 (2018).

84. Watts, A. B. Isostasy and Flexure of the Lithosphere (Cambridge Univ. Press, 2001).

85. Farrell, W. E. Deformation of the Earth by surface loads. Rev. Geophys. Space Phys. 10, 761-797 (1972).

86. Steckler, M. S. et al. Modeling Earth deformation from monsoonal flooding in Bangladesh using hydrographic, GPS, and Gravity Recovery and Climate Experiment
(GRACE) data. J. Geophys. Res. Solid Earth 115 , B08407 (2010).

87. Keogh, M. E. \& Törnqvist, T. E. Measuring rates of present-day relative sea-level rise in low-elevation coastal zones: a critical evaluation. Ocean Sci. 15 61-73 (2019).

Presents an alternative approach to tide gauges to more accurately determine the rate of RSL rise in coastal wetlands.

88. Liu, C.-W., Lin, W.-S., Shang, C. \& Liu, S.-H. The effect of clay dehydration on land subsidence in the Yun-Lin coastal area, Taiwan. Environ. Geol. 40, 518-527 (2001).

89. Teatini, P., Tosi, L. \& Strozzi, T. Quantitative evidence that compaction of Holocene sediments drives the present land subsidence of the Po Delta, Italy. J. Geophys. Res. Solid Earth 116, B08407 (2011).

90. Törnqvist, T. E. et al. Mississippi Delta subsidence primarily caused by compaction of Holocene strata. Nat. Geosci. 1, 173-176 (2008)

91. Audet, D. \& Fowler, A. A mathematical model for compaction in sedimentary basins. Geophys. J. Int. 110, 577-590 (1992).

92. Fowler, A. C. \& Yang, X.-S. Fast and slow compaction in sedimentary basins. SIAM J. Appl. Math. 59 365-385 (1998)

93. Kooi, H. \& De Vries, J. Land subsidence and hydrodynamic compaction of sedimentary basins. Hydrol. Earth Syst. Sci. Discuss. 2, 159-1 71 (1998). Applied a 1D model to investigate the compaction of basin sediments in response to sediment loading.

94. Meckel, T. A., ten Brink, U. S. \& Williams, S. J. Current subsidence rates due to compaction of Holocene sediments in southern Louisiana. Geophys. Res. Lett. 33, L1140 (2006).

95. Spasojević, S., Liu, L., Gurnis, M. \& Müller, R. D. The case for dynamic subsidence of the US east coast since the Eocene. Geophys. Res. Lett. 35, L08305 (2008).

96. Nienhuis, J. H., Törnqvist, T. E., Jankowski, K. L., Fernandes, A. M. \& Keogh, M. E. A new subsidence map for coastal Louisiana. GSA Today 27, 58-59 (2017).

97. Shirzaei, M. \& Bürgmann, R. Global climate change and local land subsidence exacerbate inundation risk to the San Francisco Bay Area. Sci. Adv. 4, eaap9234 (2018).

98. Lovelock, C. E. et al. The vulnerability of Indo-Pacific mangrove forests to sea-level rise. Nature $\mathbf{5 2 6}$ 559-563 (2015).

99. Chang, C., Mallman, E. \& Zoback, M. Time-dependent subsidence associated with drainage-induced compaction in Gulf of Mexico shales bounding a severely depleted gas reservoir. AAPG Bull. $\mathbf{9 8}$, 1145-1159 (2014).

100. Chaussard, E., Bürgmann, R., Shirzaei, M., Fielding, E. J. \& Baker, B. Predictability of hydraulic head changes and basin-wide aquifer and fault characterization from InSAR-derived ground deformation. J. Geophys. Res. Solid Earth 119 6572-6590 (2014).

101. Gambolati, G. \& Teatini, P. Geomechanics of subsurface water withdrawal and injection. Water Resour. Res. 51, 3922-3955 (2015)

102. Miller, M. M. \& Shirzaei, M. Spatiotemporal characterization of land subsidence and uplift in Phoenix using InSAR time series and wavelet transforms. J. Geophys. Res. Solid Earth 120, 5822-5842 (2015).

103. Miller, M. M., Shirzaei, M. \& Argus, D. Aquifer mechanical properties and decelerated compaction in Tucson, Arizona. J. Geophys. Res. Solid Earth 122. 8402-8416 (2017)

104. Ojha, C., Shirzaei, M., Werth, S., Argus, D. F. \& Farr, T. G. Sustained groundwater loss in California's Central Valley exacerbated by intense drought periods. Water Resour. Res. 54, 4449-4460 (2018).

105. Ojha, C., Werth, S. \& Shirzaei, M. Recovery of aquifer-systems in Southwest US following 2012-2015 drought: evidence from InSAR, GRACE and groundwater level data. J. Hydrol. 587, 124943 (2020).

106. Teatini, P., Baú, D. \& Gambolati, G. Water-gas dynamics and coastal land subsidence over Chioggia Mare field, northern Adriatic Sea. Hydrol. J. 8, 462-479 (2000).

107. Biot, M. \& Willis, D. The elastic coefficients of the theory of consolidation. J. Appl. Mech. 24, 594-601 (1957).

108. Hoffmann, J., Galloway, D. L. \& Zebker, H. A. Inverse modeling of interbed storage parameters using land subsidence observations, Antelope Valley, California Water Resour. Res. 39, 1031 (2003).

109. Terzaghi, K. Theoretical Soil Mechanics 528 (Wiley, 1943).

110. Wang, H. F. Theory of Linear Poroelasticity with Applications to Geomechanics and Hydrogeology (Princeton Univ. Press, 2000).

111. Terzaghi, K. Principles of soil mechanics, IVSettlement and consolidation of clay. Eng. News Record 95, 874-878 (1925).

112. Galloway, D. L., Jones, D. R. \& Ingebritsen, S. E. Land Subsidence in the United States Circular 1182 (US Geological Survey, 1999).

113. Chaussard, E. \& Farr, T. G. A new method for isolating elastic from inelastic deformation in aquifer systems: application to the San Joaquin Valley, CA. Geophys. Res. Lett. 46, 10800-10809 (2019).

114. Ojha, C., Werth, S. \& Shirzaei, M. Groundwater loss and aquifer system compaction in San Joaquin Valley during 2012-2015 drought. J. Geophys. Res. Solid Earth 124, 3127-3143 (2019).

115. Shirzaei, M., Ojha, C., Werth, S., Carlson, G. \& Vivoni, E. R. Comment on "Short-lived pause in Central California subsidence after heavy winter precipitation of 2017 " by K. D. Murray and R. B. Lohman. Sci. Adv. 5, eaav8038 (2019).

116. Smith, R. G. et al. Estimating the permanent loss of groundwater storage in the southern San Joaquin Valley, California. Water Resour. Res. 53, 2133-2148 (2017).

117. Scanlon, B. R. et al. Groundwater depletion and sustainability of irrigation in the US High Plains and Central Valley. Proc. Natl Acad. Sci. USA 109 9320-9325 (2012).

118. Taylor, R. G. et al. Ground water and climate change. Nat. Clim. Change 3, 322-329 (2013).

119. Minderhoud, P. S. et al. Impacts of 25 years of groundwater extraction on subsidence in the Mekong delta, Vietnam. Environ. Res. Lett. 12, 064006 (2017).

120. Erban, L. E., Gorelick, S. M. \& Zebker, H. A. Groundwater extraction, land subsidence, and sealevel rise in the Mekong Delta, Vietnam. Environ. Res. Lett. 9, 084010 (2014)

121. Minderhoud, P. S. J., Hlavacova, I., Kolomaznik, J. \& Neussner, O. Towards unraveling total subsidence of a mega-delta-the potential of new PS InSAR data for the Mekong delta. Proc. Int. Assoc. Hydrol. Sci. 382, 327-332 (2020).

122. Morton, R. A., Bernier, J. C. \& Barras, J. A. Evidence of regional subsidence and associated interior wetland loss induced by hydrocarbon production, Gulf Coast region, USA. Environ. Geol. 50, 261 (2006).

123. Qu, F. et al. Mapping ground deformation over Houston-Galveston, Texas using multi-temporal InSAR. Remote Sens. Environ. 169, 290-306 (2015).

124. Minderhoud, P. et al. The relation between land use and subsidence in the Vietnamese Mekong delta. Sci. Total Environ. 634, 715-726 (2018)

125. Hoogland, T., Van den Akker, J. \& Brus, D. Modeling the subsidence of peat soils in the Dutch coastal area. Geoderma 171, 92-97 (2012).

126. Koster, K., Stafleu, J. \& Stouthamer, E. Differential subsidence in the urbanised coastal-deltaic plain of the Netherlands. Neth. J. Geosci. 97, 215-227 (2018).

127. Murray-Wallace, C. V. \& Woodroffe, C. D. Quaternary Sea-Level Changes: A Global Perspective (Cambridge Univ. Press, 2014)

128. Shennan, I., Long, A. J. \& Horton, B. P. Handbook of Sea-Level Research (Wiley, 2015)

129. Shennan, I. Flandrian sea-level changes in the Fenland. II: Tendencies of sea-level movement, altitudinal changes, and local and regional factors. J. Quat. Sci. 1, 155-179 (1986).

130. Barlow, N. L. et al. Salt marshes as late Holocene tide gauges. Glob. Planet. Change 106, 90-110 (2013).

131. Kiden, P. Holocene relative sea-level change and crustal movement in the southwestern Netherlands. Mar. Geol. 124, 21-41 (1995).

132. Engelhart, S. E., Horton, B. P., Douglas, B. C., Peltier, W. R. \& Törnqvist, T. E. Spatial variability of late Holocene and 20th century sea-level rise along the Atlantic coast of the United States. Geology 37, 1115-1118 (2009)

133. Kemp, A., Horton, B. \& Engelhart, S. in Encyclopedia of Quaternary Science 2nd edn 489-494 (Elsevier, 2013).

134. Garrett, E. et al. Reconstructing paleoseismic deformation, 2: 1000 years of great earthquakes at Chucalén, south central Chile. Quat. Sci. Rev. 113, 112-122 (2015) 
135. Wang, K. \& Tréhu, A. M. Invited review paper: Some outstanding issues in the study of great megathrust earthquakes-The Cascadia example. J. Geodyn. 98 $1-18$ (2016)

136. Burgette, R. J., Weldon, R. J. \& Schmidt, D. A Interseismic uplift rates for western Oregon and along strike variation in locking on the Cascadia subduction zone. J. Geophys. Res. Solid Earth 114, B01408 (2009).

137. Goldfinger, C. et al. The importance of site selection, sediment supply, and hydrodynamics: a case study of submarine paleoseismology on the northern Cascadia margin, Washington USA. Mar. Geol. 384, 4-46 (2017).

138. Tanaka, H. et al. Coastal and estuarine morphology changes induced by the 2011 Great East Japan Earthquake Tsunami. Coast. Eng. J. 54, 1250010 (2012)

139. Dzurisin, D. Volcano Deformation - New Geodetic Monitoring Techniques (Springer, 2006).

140. Vaníček, P. \& Krakiwsky, E. Geodesy: The Concepts 237 (North-Holland, 1982).

141. Dzurisin, D. Geodetic leveling as a tool for studying restless in Monitoring Volcanoes; Techniques and Strategies Used by the Staff of the Cascades Volcano Observatory, 1980-90 125-134 (US Geological Survey, 1992).

142. Vanicek, P., Castle, R. O. \& Balazs, E. I. Geodetic leveling and its applications. Rev. Geophys. 18 505-524 (1980)

143. Lofgren, B. E. Measurement of compaction of aquifer systems in areas of land subsidence. US Geol. Surv. Prof. Pap. 424-B, 49-52 (1961).

144. Riley, F. S. in Land Subsidence. Proceedings of the Third International Symposium on Land Subsidence 169-186 (International Association of Hydrological Sciences, 1986).

145. Burbey, T. J. Extensometer forensics: what can the data really tell us? Hydrol. J. 28, 637-655 (2020).

146. Hung, W.-C. et al. Multiple sensors applied to monitorland subsidence in Central Taiwan. Proc. Int Assoc. Hydrol. Sci. 372, 385-391 (2015).

147. Boumans, R. M. \& Day, J. W. High precision measurements of sediment elevation in shallow coastal areas using a sedimentation-erosion table. Estuaries 16, 375-380 (1993)

148. Cahoon, D. R. et al. High-precision measurements of wetland sediment elevation: II. The rod surface elevation table. J. Sediment. Res. 72, 734-739 (2002).

149. Webb, E. L. et al. A global standard for monitoring coastal wetland vulnerability to accelerated sea-leve rise. Nat. Clim. Change 3, 458-465 (2013).

150. Cahoon, D. R. Estimating relative sea-level rise and submergence potential at a coastal wetland. Estuaries Coasts 38, 1077-1084 (2015)

151. Cahoon, D. R., Lynch, J. C. \& Knaus, R. M. Improved cryogenic coring device for sampling wetland soils. J. Sediment. Res. 66, 1025-1027 (1996).

152. Dou, S. et al. Distributed acoustic sensing for seismic monitoring of the near surface: a traffic-noise interferometry case study. Sci. Rep. 7, 11620 (2017).

153. Jousset, P. et al. Dynamic strain determination using fibre-optic cables allows imaging of seismological and structural features. Nat. Commun. 9, 2509 (2018).

154. Lindsey, N. J. et al. Fiber-optic network observation of earthquake wavefields. Geophys. Res. Lett. 44 , 11792-11799 (2017)

155. López-Higuera, J. M., Cobo, L. R., Incera, A. Q. \& Cobo, A. Fiber optic sensors in structural health monitoring. J. Lightwave Technol. 29, 587-608 (2011).

156. Sun, Y.-j. et al. Distributed acquisition, characterization and process analysis of multi-field information in slopes. Eng. Geol. 182, 49-62 (2014).

157. Zhang, C. C. et al. Vertically distributed sensing of deformation using fiber optic sensing. Geophys. Res. Lett. 45, 11732-11741 (2018).

158. Habel, W. R. \& Krebber, K. Fiber-optic sensor applications in civil and geotechnical engineering. Photonic Sens. 1, 268-280 (2011).

159. Gu, K. et al. Investigation of land subsidence with the combination of distributed fiber optic sensing techniques and microstructure analysis of soils. Eng. Geol. 240, 34-47 (2018)

160. DeWolf, S., Wyatt, F. K., Zumberge, M. A. \& Hatfield, W. Improved vertical optical fiber borehole strainmeter design for measuring Earth strain. Rev. Sci. Instrum. 86, 114502 (2015).

161. Bock, Y. \& Melgar, D. Physical applications of GPS geodesy: a review. Rep. Prog. Phys. 79, 10680 (2016).
162. Hofmann-Wellenhof, B., Lichtenegger, H. \& Collins, J. Global Positioning System: Theory and Practice 5th edn (Springer, 2000).

163. Bossler, J. D., Goad, C. C. \& Bender, P. L. Using the Global Positioning System (GPS) for geodetic positioning. Bull. Géodesique 54, 553 (1980).

164. Remondi, B. W. Performing centimeter-level surveys in seconds with GPS carrier phase: initial results. Navigation 32, 386-400 (1985)

165. Blewitt, G., Hammond, W. \& Kreemer, C. Harnessing the GPS data explosion for interdisciplinary science. Eos 99, 1-2 (2018).

166. Karegar, M. A., Larson, K. M., Kusche, J. \& Dixon, T. H. Novel quantification of shallow sediment compaction by GPS interferometric reflectometry and implications for flood susceptibility. Geophys. Res. Lett. 47, e2020GL087807 (2020)

Use GPS interferometric reflectometry to estimate shallow sediment compaction rates in the Mississippi Delta and the North Sea's eastern margin.

167. Berardino, P., Fornaro, G., Lanari, R. \& Sansosti, E. A new algorithm for surface deformation monitoring based on small baseline differential SAR interferograms. IEEE Trans. Geosci. Remote Sens. 40, 2375-2383 (2002).

168. Ferretti, A. et al. A new algorithm for processing interferometric data-stacks: SqueeSAR. IEEE Trans. Geosci. Remote Sens. 49, 3460-3470 (2011).

169. Ferretti, A., Prati, C. \& Rocca, F. Permanent scatterers in SAR interferometry. IEEE Trans. Geosci. Remote Sens. 39, 8-20 (2001).

170. Hooper, A., Zebker, H., Segall, P. \& Kampes, B. A new method for measuring deformation on volcanoes and other natural terrains using InSAR persistent scatterers. Geophys. Res. Lett. 31, L23611 (2004).

171. Massonnet, D. et al. The displacement field of the Landers earthquake mapped by radar interferometry. Nature 364, 138-142 (1993)

172. Bürgmann, R., Rosen, P. A. \& Fielding, E. J. Synthetic aperture radar interferometry to measure Earth's surface topography and its deformation. Annu. Rev. Earth Planet. Sci. 28, 169-209 (2000).

173. Hanssen, R. F. Radar Interferometry: Data Interpretation and Error Analysis (Kluwer, 2001)

174. Moreira, A. et al. A tutorial on synthetic aperture radar. IEEE Geosci. Remote Sens. Mag. 1, 6-43 (2013).

175. Franceschetti, G. \& Lanari, R. Synthetic Aperture Radar Processing 328 (CRC Press, 1999).

176. Zebker, H. \& Villasenor, J. Decorrelation in interferometric radar echoes. IEEE Trans. Geosci. Remote Sens. 30, 950-959 (1992)

177. Ferretti, A., Monti-Guarnieri, A., Prati, C., Rocca, F. \& Massonnet, D. InSAR Principles: Guidelines for SAR Interferometry Processing and Interpretation (ed. Fletcher, K.) 48 (ESA Publications, 2007).

178. Altamimi, Z., Rebischung, P., Métivier, L. \& Collilieux, X ITRF2014: A new release of the International Terrestrial Reference Frame modeling nonlinear station motions. J. Geophys. Res. Solid Earth 121, 6109-6131 (2016).

179. Allison, M. et al. Global risks and research priorities for coastal subsidence. Eos 97, 22-27 (2016).

180. Blackwell, E., Shirzaei, M., Ojha, C. \& Werth, S. Tracking California's sinking coast from space: implications for relative sea-level rise. Sci. Adv. $\mathbf{6}$, eaba4551 (2020).

Obtains the first high-resolution map of VLM along California's coast by combining InSAR and GNSS data.

181. Okada, Y. Surface deformation due to shear and tensile faults in a half-space. Bull. Seismol. Soc. Am. 75, 1135-1154 (1985).

182. Okada, Y. Internal deformation due to shear and tensile faults in a half-space. Bull. Seismol. Soc. Am. 82, 1018-1040 (1992)

183. Bürgmann, R. \& Dresen, G. Rheology of the lower crust and upper mantle: evidence from rock mechanics, geodesy, and field observations. Annu. Rev. Earth Planet. Sci. 36, 531-567 (2008).

184. Schmalzle, G. M., McCaffrey, R. \& Creager, K. C. Central Cascadia subduction zone creep. Geochem. Geophys. Geosyst. 15, 1515-1532 (2014).

185. Wang, P. L. et al. Heterogeneous rupture in the great Cascadia earthquake of 1700 inferred from coastal subsidence estimates. J. Geophys. Res. Solid Earth 118, 2460-2473 (2013)

186. Briggs, R. W. et al. Uplift and subsidence reveal a nonpersistent megathrust rupture boundary (Sitkinak Island, Alaska). Geophys. Res. Lett. 41, 2289-2296 (2014).
187. Sieh, K. et al. Earthquake supercycles inferred from sea-level changes recorded in the corals of west Sumatra. Science 322, 1674-1678 (2008).

188. Leonard, L. J., Hyndman, R. D. \& Mazzotti, S Coseismic subsidence in the 1700 great Cascadia earthquake: coastal estimates versus elastic dislocation models. Geol. Soc. Am. Bull. 116 655-670 (2004).

189. Savage, J. C. A dislocation model of strain accumulation and release at a subduction zone. J. Geophys. Res. 88, 4984-4996 (1983).

190. Plafker, G. Alaskan earthquake of 1964 and Chilean earthquake of 1960: implications for arc tectonics. J. Geophys. Res. 77, 901-925 (1972).

191. Ely, L. L., Cisternas, M., Wesson, R. L. \& Dura, T. Five centuries of tsunamis and land-level changes in the overlapping rupture area of the 1960 and 2010 Chilean earthquakes. Geology 42, 995-998 (2014).

192. Garrett, E., Shennan, I., Watcham, E. \& Woodroffe, S. Reconstructing paleoseismic deformation, 1: modern analogues from the 1960 and 2010 Chilean great earthquakes. Quat. Sci. Rev. 75, 11-21 (2013).

193. Feng, L. et al. Active deformation near the Nicoya Peninsula, northwestern Costa Rica, between 1996 and 2010: interseismic megathrust coupling. J. Geophys. Res. Solid Earth 117, B06407 (2012).

194. Protti, M. et al. Nicoya earthquake rupture anticipated by geodetic measurement of the locked plate interface. Nat. Geosci. 7, 117-121 (2014)

195. Muto, J. et al. Coupled afterslip and transient mantle flow after the 2011 Tohoku earthquake. Sci. Adv. $\mathbf{5}$. eaaw1164 (2019).

196. Suito, H. \& Freymueller, J. T. A viscoelastic and afterslip postseismic deformation model for the 1964 Alaska earthquake. J. Geophys. Res. Solid Earth 114 , B11404 (2009).

197. Peltier, W. R., Argus, D. F. \& Drummond, R. Space geodesy constrains ice age terminal deglaciation: the global ICE-6G_C (VM5a) model. J. Geophys. Res. Solid Earth 120, 450-487 (2015).

198. Shennan, I. et al. Late Devensian and Holocene records of relative sea-level changes in northwest Scotland and their implications for glacio-hydroisostatic modelling. Quat. Sci. Rev. 19, 1103-1135 (2000).

199. Kuchar, J., Milne, G. \& Latychev, K. The importance of lateral Earth structure for North American glacial isostatic adjustment. Earth Planet. Sci. Lett. $\mathbf{5 1 2}$ 236-245 (2019)

200. Love, R. et al. The contribution of glacial isostatic adjustment to projections of sea-level change along the Atlantic and Gulf coasts of North America. Earth's Future 4, 440-464 (2016).

One of the most rigorous comparisons of GIA model and RSL data to date, partly based on 3D Earth models.

201. Wu, P. \& van der Wal, W. Postglacial sealevels on a spherical, self-gravitating viscoelastic earth: effects of lateral viscosity variations in the upper mantle on the inference of viscosity contrasts in the lower mantle. Earth Planet. Sci. Lett. 211, 57-68 (2003).

202. Tarasov, L., Dyke, A. S., Neal, R. M. \& Peltier, W. R. A data-calibrated distribution of deglacial chronologies for the North American ice complex from glaciological modeling. Earth Planet. Sci. Lett. 315, 30-40 (2012).

203. Hu, Y. \& Freymueller, J. T. Geodetic observations of time-variable glacial isostatic adjustment in southeast Alaska and its implications for Earth rheology. J. Geophys. Res. Solid Earth $\mathbf{1 2 4}$, 9870-9889 (2019).

204. Ivins, E. R. \& James, T. S. Bedrock response to Llanquihue Holocene and present-day glaciation in southernmost South America. Geophys. Res. Lett. 31, L24613 (2004).

205. Richter, A. et al. Crustal deformation across the Southern Patagonian Icefield observed by GNSS Earth Planet. Sci. Lett. 452, 206-215 (2016).

206. Auriac, A. et al. Iceland rising: Solid Earth response to ice retreat inferred from satellite radar interferometry and visocelastic modeling. J. Geophys. Res. Solid Earth 118, 1331-1344 (2013).

207. Nield, G. A. et al. Rapid bedrock uplift in the Antarctic Peninsula explained by viscoelastic response to recent ice unloading. Earth Planet. Sci. Lett. 397, 32-41 (2014).

208. Ortega-Guerrero, A., Rudolph, D. L. \& Cherry, J. A Analysis of long-term land subsidence near Mexico City: field investigations and predictive modeling. Water Resour. Res. 35, 3327-3341 (1999)

209. Zhang, Y., Xue, Y., Wu, J., Wang, H. \& He, J. Mechanical modeling of aquifer sands under long-term 
groundwater withdrawal. Eng. Geol. 125, 74-80

(2012).

210. Zhang, Y., Xue, Y., Wu, J. \& Wang, Z. Compaction of aquifer units under complex patterns of changing groundwater level. Environ. Earth Sci. 73, 1537-1544 (2015)

211. Burbey, T. J. Effects of horizontal strain in estimating specific storage and compaction in confined and leaky aquifer systems. Hydrol. J. 7, 521-532 (1999).

212. Gambolati, G. A three-dimensional model to compute land subsidence. Hydrol. Sci. J. 17, 219-226 (1972).

213. Geertsma, J. in Proceedings of the 1st ISRM Congress (International Society for Rock Mechanics and Rock Engineering, 1966)

214. Biot, M. A. General theory of three-dimensional consolidation. J. Appl. Phys. 12, 155-164 (1941).

215. Biot, M. A. Theory of elasticity and consolidation for a porous anisotropic solid. J. Appl. Phys. 26, 182-185 (1955).

216. Rice, J. R. \& Cleary, M. P. Some basic stress diffusion solutions for fluid-saturated elastic porous media with compressible constituents. Rev. Geophys. Space Phys. 14, 227-241 (1976)

217. Gambolati, G. \& Freeze, R. A. Mathematical simulation of the subsidence of Venice: 1 . Theory. Water Resour. Res. 9, 721-733 (1973).

The first regional numerical model to simulate and predict coastal subsidence following groundwater extraction.

218. Gambolati, G., Gatto, P. \& Freeze, R. A. Mathematical simulation of the subsidence of Venice: 2 . Results. Water Resour. Res. 10, 563-577 (1974).

219. Helm, D. C. One-dimensional simulation of aquifer system compaction near Pixley, California: 1. Constant parameters. Water Resour. Res. 11 465-478 (1975)

220. Helm, D. C. One-dimensional simulation of aquifer system compaction near Pixley, California: 2. Stress-dependent parameters. Water Resour. Res. 12 375-391 (1976)

221. Leake, S. Interbed storage changes and compaction in models of regional groundwater flow. Water Resour. Res. 26, 1939-1950 (1990).

222. Corapcioglu, M. Y. \& Brutsaert, W. Viscoelastic aquifer model applied to subsidence due to pumping. Water Resour. Res. 13, 597-604 (1977).

223. Darcy, H. The Public Fountains of the City of Dijon. 647 (Kendall Hunt, 1856)

224. Shirzaei, M., Ellsworth, W. L., Tiampo, K. F. González, P. J. \& Manga, M. Surface uplift and time dependent seismic hazard due to fluid injection in eastern Texas. Science 353, 1416-1419 (2016).

225. Bjerrum, L. Engineering geology of Norwegian normally-consolidated marine clays as related to settlements of buildings. Geotechnique 17, 83-118 (1967).

226. Buisman, A in Proceedings of the 1st International Conference on Soil Mechanics and Foundation Engineering 103-106 (Cambridge, 1936).

227. Gray, H. in Proceedings of the 1st Internationa Conference on Soil Mechanics and Foundation Engineering 138-141 (Cambridge, 1936).

228. Zhang, Y., Wang, Z., Xue, Y. \& Wu, J. Visco-elastoplastic compaction of aquitards due to groundwater withdrawal in Shanghai, China. Environ. Earth Sci. 74 1611-1624 (2015)

229. Comola, F. et al. Efficient global optimization of reservoir geomechanical parameters based on synthetic aperture radar-derived ground displacements. Geophysics 81, M23-M33 (2016).

230. Kihm, J.-H., Kim, J.-M., Song, S.-H. \& Lee, G.-S. Three-dimensional numerical simulation of fully coupled groundwater flow and land deformation due to groundwater pumping in an unsaturated fluvial aquifer system. J. Hydrol. 335, 1-14 (2007).

231. Rutqvist, J., Vasco, D. W. \& Myer, L. Coupled reservoirgeomechanical analysis of $\mathrm{CO}_{2}$ injection and ground deformations at In Salah, Algeria. Int. J. Greenh. Gas Control. 4, 225-230 (2010).

232. Shirzaei, M., Manga, M. \& Zhai, G. Hydraulic properties of injection formations constrained by surface deformation. Earth Planet. Sci. Lett. $\mathbf{5 1 5}$ 125-134 (2019).

233. Teatini, P., Ferronato, M., Gambolati, G. \& Gonella, M Groundwater pumping and land subsidence in the Emilia-Romagna coastland, Italy: modeling the past occurrence and the future trend. Water Resour. Res. 42, W01406 (2006)

234. Teatini, P., Gambolati, G., Ferronato, M., Settari, A. T. $\&$ Walters, D. Land uplift due to subsurface fluid injection. J. Geodyn. 51, 1-16 (2011).
235. Ye, S. et al. Three-dimensional numerical modeling of land subsidence in Shanghai, China. Hydrol. J. 24 695-709 (2016).

236. Bethke, C. M. A numerical model of compaction-driven groundwater flow and heat transfer and its application to the paleohydrology of intracratonic sedimentary basins. J. Geophys. Res. Solid Earth 90, 6817-6828 (1985).

237. Ungerer, P., Burrus, J., Doligez, B., Chenet, P. \& Bessis, F. Basin evaluation by integrated two dimensional modeling of heat transfer, fluid flow, hydrocarbon generation, and migration (1). AAPC Bull. 74, 309-335 (1990).

238. Zoccarato, C. \& Teatini, P. Numerical simulations of Holocene salt-marsh dynamics under the hypothesis of large soil deformations. Adv. Water Res. 110 107-119 (2017)

A novel approach to modelling sediment deposition and shallow compaction in coastal wetlands that accounts for large deformations and changing soil properties.

239. Kolker, A. S., Allison, M. A. \& Hameed S. An evaluation of subsidence rates and sea-level variability in the northern Gulf of Mexico. Geophys. Res. Lett. 38, L21404 (2011)

240. Texas General Land Office. Texas coastal Resiliency Master Plan. Texas General Land Office https://www. glo.texas.gov/coastal-grants/projects/files/MasterPlan.pdf (2017).

241. National Research Council. Sea-Level Rise for the Coasts of California, Oregon, and Washington: Past, Present, and Future (The National Academies Press, 2012).

242. Nordhaus, W. D. The economics of hurricanes and implications of global warming. Clim. Change Econ. 1 $1-20$ (2010)

243. Coastal Protection and Restoration Authority of Louisiana. Louisiana's Comprehensive Master Plan for a Sustainable Coast (Coastal Protection and Restoration Authority of Louisiana, 2017).

244. Bekaert, D., Hamlington, B., Buzzanga, B. \& Jones, C. Spaceborne synthetic aperture radar survey of subsidence in Hampton Roads, Virginia (USA). Sci. Rep. 7, 14752 (2017)

245. Karegar, M. A., Dixon, T. H. \& Engelhart, S. E. Subsidence along the Atlantic Coast of North America insights from GPS and late Holocene relative sea level data. Geophys. Res. Lett. 43, 3126-3133 (2016). Integration of subsidence observations over short and long timescales that elucidates the role of fluid extraction.

246. Ng, A. H.-M. et al. Mapping land subsidence in Jakarta, Indonesia using persistent scatterer interferometry (PSI) technique with ALOS PALSAR. Int. J. Appl. Earth Obs. Geoinf. 18, 232-242 (2012).

247. Raucoules, D. et al. High nonlinear urban ground motion in Manila (Philippines) from 1993 to 2010 observed by DInSAR: implications for sea-level measurement. Remote Sens. Environ. 139, 386-397 (2013).

248. Miller, M. M. \& Shirzaei, M. Land subsidence in Houston correlated with flooding from Hurricane Harvey. Remote Sens. Environ. 225, 368-378 (2019). Shows that Houston flooding following Hurricane Harvey correlates with long-term coastal subsidence.

249. Gao, X. \& Wang, K. L. Strength of stick-slip and creeping subduction megathrusts from heat flow observations. Science 345, 1038-1041 (2014).

250. Khoshmanesh, M., Shirzaei, M. \& Uchida, N. Deep slow-slip events promote seismicity in northeastern Japan megathrust. Earth Planet. Sci. Lett. 540 116261 (2020).

251. Carpenter, B. M., Marone, C. \& Saffer, D. M. Weakness of the San Andreas Fault revealed by samples from the active fault zone. Nat. Geosci. 4, 251-254 (2011).

252. Lockner, D. A., Morrow, C., Moore, D. \& Hickman, S. Low strength of deep San Andreas fault gouge from SAFOD core. Nature 472, 82-85 (2011).

253. Sibson, R. H. Fault zone models, heat flow, and the depth distribution of earthquakes in the continental crust of the United States. Bull. Seismol. Soc. Am. 72, 151-163 (1982)

254. Khoshmanesh, M. \& Shirzaei, M. Episodic creep events on the San Andreas Fault caused by pore pressure variations. Nat. Geosci. 11, 610-614 (2018)

255. Kodaira, S. et al. High pore fluid pressure may cause silent slip in the Nankai trough. Science 304 1295-1298 (2004).

256. Rice, J. R. in Fault Mechanics and Transport Properties of Rocks (eds Evans, B. \& Wong, T.-F.) 475-503 (Academic, 1992).
257. Kemp, A. C., Cahill, N., Engelhart, S. E., Hawkes, A. D. $\&$ Wang, K. Revising estimates of spatially variable subsidence during the $A D 1700$ Cascadia earthquake using a Bayesian foraminiferal transfer function. Bull. Seismol. Soc. Am. 108, 654-673 (2018).

258. Yousefi, M. Milne, G. Li, S., Wang, K. \& Bartholet, A. Constraining interseismic deformation of the Cascadia subduction zone: new insights from estimates of vertical land motion over different timescales. J. Geophys. Res. Solid Earth 125, e2019JB018248 (2020).

Constrains megathrust locking models of the Cascadia subduction zone using RSL observations and GPS data.

259. Bevis, M. et al. Accelerating changes in ice mass within Greenland, and the ice sheet's sensitivity to atmospheric forcing. Proc. Natl Acad. Sci. USA 116 1934-1939 (2019).

260. Harig, C. \& Simons, F. J. Mapping Greenland's mass loss in space and time. Proc. Natl Acad. Sci. USA 109 19934-19937 (2012).

261. Mouginot, J. et al. Forty-six years of Greenland ice sheet mass balance from 1972 to 2018. Proc. Natl Acad. Sci. USA 116, 9239-9244 (2019).

262. Shepherd, A. et al. Mass balance of the Greenland Ice Sheet from 1992 to 2018. Nature 579, 233-239 (2019).

263. Eriyagama, N., Muthuwatta, L. \& Thilakarathne, M. in Proceedings of the Disaster Management Conference The future we want-Safer Sri Lanka, Colombo, Sri Lanka 379-381 (Ministry of Disaster Management, 2014).

264. Higgins, S., Overeem, I., Tanaka, A. \& Syvitski, J. P. Land subsidence at aquaculture facilities in the Yellow River delta, China. Geophys. Res. Lett. 40, 3898-3902 (2013).

265. Riel, B., Simons, M., Ponti, D. Agram, P. \& Jolivet, R Quantifying ground deformation in the Los Angeles and Santa Ana Coastal Basins due to groundwater withdrawal. Water Resour. Res. 54, 3557-3582 (2018).

266. Wang, R. \& Kümpel, H.-J. Poroelasticity: efficient modelling of strongly coupled, slow deformation processes in a multilayered half-space. Geophysics 68 705-717 (2003)

267. Wang, S.-J., Lee, C.-H. \& Hsu, K.-C. A technique for quantifying groundwater pumping and land subsidence using a nonlinear stochastic poroelastic model. Environ. Earth Sci. 73, 8111-8124 (2015).

268. Diffenbaugh, N. S., Swain, D. L. \& Touma, D. Anthropogenic warming has increased drought risk in California. Proc. Natl Acad. Sci. USA 112. 3931-3936 (2015).

269. Meixner, T. et al. Implications of projected climate change for groundwater recharge in the western United States. J. Hydrol. 534, 124-138 (2016).

270. Niraula, R. et al. How might recharge change under projected climate change in the western US? Geophys. Res. Lett. 44, 10,407-410,418 (2017)

271. Smerdon, B. D. A synopsis of climate change effects on groundwater recharge. J. Hydrol. 555, 125-128 (2017).

272. Tillman, F. D., Gangopadhyay, S. \& Pruitt, T. Changes in groundwater recharge under projected climate in the upper Colorado River basin. Geophys. Res. Lett. 43, 6968-6974 (2016).

273. Vitousek, S. et al. Doubling of coastal flooding frequency within decades due to sea-level rise. Sci. Rep. 7, 1399 (2017)

274. Knowles, N. Potential inundation due to rising sea levels in the San Francisco Bay Region. San Franc. Estuary Watershed Sci. https://doi.org/10.15447/ sfews.2010v8iss 1 art1 (2010).

275. Barnard, P. L., Schoellhamer, D. H., Jaffe, B. E. \& McKee, L. J. Sediment transport in the San Francisco Bay coastal system: an overview. Mar. Geol. 345, 3-17 (2013).

276. Dragert, H., Hyndman, R. D., Rogers, G. C. \& Wang, K Current deformation and the width of the seismogenic zone of the northern Cascadia subduction thrust. J. Geophys. Res. 99, 653-668 (1994).

277. Rocca, F., Rucci, A., Ferretti, A \& Bohane, A. Advanced InSAR interferometry for reservoir monitoring. First Break 31, 77-85 (2013)

278. Pfeffer, J. \& Allemand, P. The key role of vertical land motions in coastal sea level variations: a global synthesis of multisatellite altimetry, tide gauge data and GPS measurements. Earth Planet. Sci. Lett. 439, 39-47 (2016)

279. Wang, R. J. \& Kumpel, H. J. Poroelasticity: efficient modeling of strongly coupled, slow deformation 
processes in a multilayered half-space. Geophysics 68 705-717 (2003)

280. Horton, B. P. et al. Mapping sea-level change in time space, and probability. Annu. Rev. Environ. Resour. 43, 481-521 (2018).

281. Griggs, G. et al. Rising Seas in California: An Update on Sea-Level Rise Science (California Ocean Science Trust, 2017)

282. Strozzi, T., Teatini, P., Tosi, L., Wegmüller, U. $\delta$ Werner, C. Land subsidence of natural transitional environments by satellite radar interferometry on artificial reflectors. J. Geophys. Res. Earth Surf. 118 1177-1191 (2013)

283. Da Lio, C., Teatini, P., Strozzi, T. \& Tosi, L. Understanding land subsidence in salt marshes of the Venice Lagoon from SAR Interferometry and groundbased investigations. Remote Sens. Environ. 205 56-70 (2018).

284. Fiaschi, S. \& Wdowinski, S. Local land subsidence in Miami Beach (FL) and Norfolk (VA) and its contribution to flooding hazard in coastal communities along the US Atlantic coast. Ocean Coast. Manag. 187 105078 (2020).

285. Shirzaei, M. A wavelet-based multitemporal DInSAR algorithm for monitoring ground surface motion. IEEE Geosci. Remote Sens. Lett. 10, 456-460 (2013).

286. Hooper, A., Segall, P. \& Zebker, H. Persistent scatterer interferometric synthetic aperture radar for crustal deformation analysis, with application to Volcán Alcedo, Galápagos. J. Geophys. Res. Solid Earth 112, B07407 (2007).

287. Jolivet, R., Grandin, R., Lasserre, C., Doin, M. P. \& Peltzer, G. Systematic InSAR tropospheric phase delay corrections from global meteorological reanalysis data. Geophys. Res. Lett. 38, L17311 (2011)

288. Yu, C., Li, Z., Penna, N. T. \& Crippa, P. Generic atmospheric correction model for Interferometric Synthetic Aperture Radar observations. J. Geophys. Res. Solid Earth 123, 9202-9222 (2018).

289. Yu, C., Penna, N. T. \& Li, Z. Generation of real-time mode high-resolution water vapor fields from GPS observations. J. Geophys. Res. Atmos. 122 2008-2025 (2017).
290. Hu, J. et al. Resolving three-dimensional surface displacements from InSAR measurements: a review. Earth Sci. Rev. 133, 1-17 (2014).

291. Fialko, Y., Sandwell, D., Simons, M. \& Rosen, P. Threedimensional deformation caused by the Bam, Iran, earthquake and the origin of shallow slip deficit. Nature 435, 295-299 (2005).

292. Jung, H.-S., Lu, Z., Won, J.-S., Poland, M. P. \& Miklius, A. Mapping three-dimensional surface deformation by combining multiple-aperture interferometry and conventional interferometry: Application to the June 2007 eruption of Kilauea volcano, Hawaii. IEEE Geosci. Remote Sens. Lett. 8 34-38 (2010).

293. Wright, T. J., Parsons, B. E. \& Lu, Z. Toward mapping surface deformation in three dimensions using InSAR. Geophys. Res. Lett. 31, L01607 (2004).

294. Joughin, I. R., Kwok, R. \& Fahnestock, M. A Interferometric estimation of three-dimensional ice-flow using ascending and descending passes. IEEE Trans. Geosci. Remote Sens. 36, 25-37 (1998).

295. Mohr, J. J., Reeh, N. \& Madsen, S. N. Threedimensional glacial flow and surface elevation measured with radar interferometry. Nature 391, 273-276 (1998)

296. Tymofyeyeva, E. \& Fialko, Y. Geodetic evidence for a blind fault segment at the southern end of the San Jacinto fault zone. J. Geophys. Res. Solid Earth 123 , 878-891 (2018)

297. Guglielmino, F., Nunnari, G., Puglisi, G. \& Spata, A. Simultaneous and integrated strain tenso estimation from geodetic and satellite deformation measurements to obtain three-dimensional displacement maps. IEEE Trans. Geosci. Remote Sens. 49, 1815-1826 (2011).

298. Samsonov, S. \& Tiampo, K. Analytical optimization of a DInSAR and GPS dataset for derivation of threedimensional surface motion. IEEE Geosci. Remote Sens. Lett. 3, 107-111 (2006)

\section{Acknowledgements}

The authors thank the reviewers for providing insightful comments and suggestions and J. Flocks for providing constructive comments on the manuscript. M.S. is supported by the
US National Aeronautics and Space Administration (grant no. 80NSSC170567) and the US National Science Foundation (grant no. EAR-1735630). J.F. is supported by the US National Aeronautics and Space Administration (grant no. 80 NSSC 17K0566). T.E.T. has been supported by the US National Science Foundation (grant no. EAR-1349311). T.D. is supported by the US National Science Foundation (grant nos. EAR-1624795 and EAR-1624533). P.S.J.M. is supported by an EU Marie Skłodowska-Curie Individual Fellowship (grant no. 894476 - InSPiRED - H2020MSCA-IF-2019). This work is a contribution to the PALSEA programme and International Geoscience Programme (IGCP) project 639. Any use of trade, firm or product names is for descriptive purposes only and does not imply endorsement by the US Government.

\section{Author contributions}

M.S. and J.F. wrote the manuscript. All authors contributed to the discussion of content and edited the manuscript prior to submission.

\section{Competing interests}

The authors declare no competing interests.

Peer review information

Nature Reviews Earth \& Environment thanks S. Wdowinski, M. Karegar and the other, anonymous, reviewer(s) for their contribution to the peer review of this work.

\section{Publisher's note}

Springer Nature remains neutral with regard to jurisdictional claims in published maps and institutional affiliations.

\section{RELATED LINKS}

Harris-Galveston Subsidence District: https://hgsubsidence.

org/science-research/what-is-subsidence/

Nevada Geodetic Laboratory: http://geodesy.unr.edu/

P403 station: https://www.unavco.org/instrumentation/

networks/status/nota/overview/P403

SONEL: http://www.sonel.org/-GPS-.html

UNAVCO: https://www.unavco.org/

(c) Springer Nature Limited 2020, corrected publication 2020 